\title{
Copyright
}

by

Marcy Lynn Shepardson

2012 
The Dissertation Committee for Marcy Lynn Shepardson certifies that this is the approved version of the following dissertation:

\section{Audit committee member contextual experiences and financial reporting outcomes}

\section{Committee:}

William R. Kinney Jr., Supervisor

Shuping Chen

William Cunningham

Roger D. Martin

Yong $\mathrm{Yu}$ 


\title{
Audit committee member contextual experiences and financial reporting outcomes
}

\author{
by \\ Marcy Lynn Shepardson, BA, MSAcc \\ Presented to the Faculty of the Graduate School of \\ The University of Texas at Austin \\ In Partial Fulfillment \\ of the Requirements \\ for the Degree of
}

\section{Doctor of Philosophy}

The University of Texas at Austin

May, 2012 


\section{Acknowledgements}

I would first and foremost like to thank my parents, Phil and Nancy Shepardson, for their support throughout not only this process but my entire life. I wish that every child could be so lucky as to have parents like mine.

I would also like to thank the doctoral students and faculty at the University of Texas at Austin as well as the wonderful friends I made in Austin along the way. My doctoral program was a true pleasure due almost entirely to the people of Austin and in retrospect there is not a thing that I would change. I would like to thank my dissertation committee, Shuping Chen, Bill Cunningham, Roger Martin, and Yong Yu, very much for their comments and support throughout this process.

Finally, I cannot thank my committee chair, Bill Kinney, enough. Bill has taught me so many things about writing, thinking, commitment, and life. I am still amazed by, and will be forever grateful for, his generosity and friendship. 


\title{
Audit committee member contextual experiences and financial reporting outcomes
}

\author{
Publication No. \\ Marcy Lynn Shepardson, Ph.D. \\ The University of Texas at Austin, 2012 \\ Supervisor: William R. Kinney, Jr.
}

Contextual experience with the practical application of accounting standards is important for independent audit committee members to effectively monitor managers’ financial reporting estimates and the audits of those estimates. Basic knowledge of accounting standards can be acquired by reading public documents and some degree of information regarding firm-specific application of standards can be obtained from public disclosures. However, real-world, contextual experience may best be obtained through performing or monitoring the reporting tasks themselves. This dissertation investigates how a firm's (focal firm) financial reporting monitoring activities are affected by its audit committee members' contextual experiences gained through connections, either as managers or audit committee members, with other firms (links or interlocks).

I specifically estimate whether contextual experience with significant judgments and estimates, measured as interlocks with firms that likely performed extensive impairment analyses in the prior year (distressed firms), affects the likelihood of focal 
firm decisions to write off goodwill after controlling for economic indicators of impairment, managerial incentives to misreport, and ability of managers to exercise discretion.

I find that the likelihood of write-off is significantly greater for firms with links to distressed firms than firms without links, consistent with audit committee contextual experience influencing financial reporting outcomes. The distressed firm interlock effect is significantly greater when the contextual experience at the linked firm is in the performance of estimates as a manager in contrast to the monitoring of estimates as an audit committee member. However, in a subset of large firms with ExecuComp data, I find that the overall probability of write-off is decreasing across quartiles of managerial incentives to misreport and received interlocks are only marginally significant in the second quartile, indicating that contextual experience may not be an effective monitoring mechanism when managerial incentives to misreport are high.

Combined results suggest that contextual experiences obtained through audit committee network associations do affect focal firm financial reporting outcomes and are most influential when the contextual experience is as a manager, rather than a monitor. However, such monitoring mechanisms appear to be primarily imitative and may not be effective deterrents against managerial misreporting at large firms when managerial equity-based incentives are strong. 


\section{Table of Contents}

List of Figures and Tables..................................................viii

Chapter 1: Introduction......................................................1

Chapter 2: Extant research.......................................................

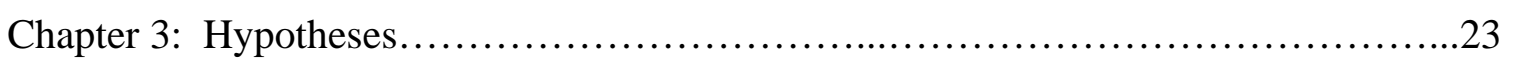

Chapter 4: Data, models, and descriptive statistics..............................27

Chapter 5: Results....................................................43

Chapter 6: Sensitivity analyses...............................................49

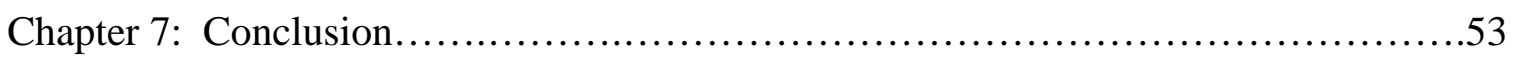

Figures and Tables....................................................... 55

References..............................................................77

Vita..................................................................... 82 


\section{List of Figures and Tables}

Figure 1 Contextual Experience Obtained through Audit Committee Links..............55

Table 1 Sample Selection and Industry Summary .................................56

Table 2 Summary Statistics of Independent and Control Variables.....................57

Table 3 Selected Descriptive Statistics by Year..................................60

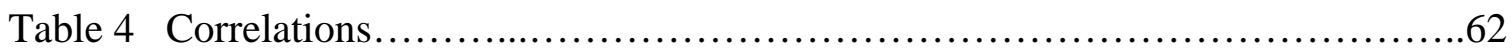

Table 5 Logistic Regressions of Goodwill Impairment Decision on Interlock and Control Variables............................................63

Table 6 Marginal Effects of Goodwill Impairment Decision on Interlock and Control Variables..............................................65

Table 7 Logistic Regressions of Goodwill Impairment Decision on Interlock and Control Variables by Incentive Ratio Quartile...................67

Table 8 Marginal Effects of Goodwill Impairment Decision on Interlock and Control Variables by Incentive Ratio Quartile....................69

Table 9 Two-stage Heckman Model...............................................70

Table 10 Propensity Score Matched Sample.....................................73

Table 11 Differences in Means of Independent Variables Within High and Low Propensity to Write-off Firms..............................76 


\section{Chapter 1: Introduction}

Financial statements prepared by corporate management using standards-based measurement methods and audited by independent auditors comprise the primary corporate performance measurement system, world-wide. In the United States, the independent audit committee of part-time, non-management (“independent”) board members is required to oversee both corporate financial reporting by management and audits by independent auditors (U.S. Congress 2002).

Mandated audit committee member independence and audit committee member financial expertise are intended to facilitate unbiased and effective monitoring of managers who may report in a self-interested manner, which may not be in the best interest of shareholders and other stakeholders. Independence necessarily limits the range and amount of firm-specific information and firm-specific contextual experience that audit committee members can have. Thus, audit committees must rely on information provided by members of management, auditors, and contextual experience gained from external sources to inform their judgments and decisions about firm financial reporting.

Judgments and decisions, and their oversight, become more important as accounting standards continue to evolve from historical cost to more fair value reporting methods that require greater levels of estimation, resulting in increasing ranges of appropriate values of assets and liabilities from which to choose. The existence of managerial preferences for specific accounting outcomes coupled with more estimation in 
financial reporting highlight the importance of oversight by independent and informed monitors.

The U.S. Securities and Exchange Commission (SEC) stated that audit committee financial experts should have "a thorough understanding of the audit committee's oversight role, expertise in accounting matters as well as understanding of financial statements, and the ability to ask the right questions to determine whether the company's financial statements are complete and accurate” (SEC 2003). Basic knowledge of financial accounting and auditing standards can be acquired by reading public documents and a general understanding of these standards can narrow the range of acceptable accounting methods or values from which to choose. Some degree of firm-specific information regarding application of standards can be obtained from publicly available disclosures; however, such disclosures provide only limited information regarding the methods used and assumptions made in accounting judgments and estimates. Realworld, contextual experience regarding practical application of standards and the understanding of trade-offs made during application can be obtained through performing or monitoring tasks themselves.

Audit committee members obtain contextual experience about how to monitor difficult accounting estimates and which questions to ask through experiences as audit committee members (monitoring contextual experience) or as managers (performance contextual experience). A thorough understanding of the audit committee's role can be obtained through performance on or interaction with audit committees, and thus can be 
gained at one firm over time or at multiple firms. Because "most outside directors of open corporations are either managers of other corporations or important decision makers in other complex organizations” (Fama and Jensen 1983), audit committee members likely use knowledge obtained as audit committee members or managers at other firms (linked firms) to inform independent oversight behaviors in their present audit committee role (focal firm).

Differences in type of contextual experience are important when assessing the abilities of audit committee members to monitor accounting judgments and estimates. Audit committee members may obtain monitoring contextual experience across multiple firms by reviewing management's calculations and analyses or discussing estimates and alternatives with managers and auditors. ${ }^{1}$ While the range of involvement of audit committee members in financial reporting decisions and outcomes is likely broad, a directors’ own experience developing and reporting accounting estimates as a firm manager should provide the richest contextual experience that they can apply when performing monitoring duties at other firms.

While lawmakers intend that audit committees affect financial reporting (US Congress 2002), some may argue that any effects are, at best, third or fourth order following underlying economics, managerial effects, and auditor input. Prior research has argued that audit committees are created to comply with requirements rather than to functionally monitor self-interested managers (Cohen, Krishnamoorthy, and Wright

\footnotetext{
${ }^{1}$ One audit committee chair said "I compare across my three audit committees to identify things to focus on and to benchmark company practices - there are great spillover benefits of serving on three audit committees” (Beasley, Carcello, Hermanson, and Neal 2009).
} 
2010). From this perspective, it would be unlikely to identify effects of audit committee members on specific reporting decisions. However, other studies assume that audit committees do affect financial reporting and have attempted to answer the question of how via interview-based (Beasley, Carcello, Hermanson, and Neal 2009) and experimental methods (e.g. Agoglia, Doupnik, and Tsakusis 2011; McDaniel, Martin, and Maines 2002). Two concurrent archival studies of large firms have found that "bad" behavior, as measured by high levels of discretionary accruals and/or restatements, “travels” through audit committees (Chiu, Teoh, and Tian 2010; Shi, Dharwadkar, and Harris 2012), but neither identifies a specific mechanism.

In this study, I use a unique research design and a larger and more diverse sample than the two concurrent studies ${ }^{2}$ to archivally answer questions regarding not only whether audit committee members affect joint financial reporting outcomes, but also how. I address the question "when accounting standards allow for estimation and interpretation, does audit committee member contextual experience gained at other firms affect financial reporting outcomes”? Using focal firm audit committee member relationships (links or interlocks) with other firms, either as audit committee members or managers, I test whether audit committee members’ experiences with difficult accounting estimates, measured as recent experience with goodwill impairment analyses, affect the current year probability of write-off of firms on whose audit committees they currently sit.

\footnotetext{
${ }^{2}$ The use of BoardEx data provides two improvements. First, the number of firm-year observations is increased and includes smaller firms than studies that use ExecuComp data. Second, I am able to identify interlocks with smaller firms, whereas these concurrent studies only identify links among S\&P 1500 firms, thus ignoring potentially important effects.
} 
All firms with recorded goodwill are required to determine, at least annually, whether existing goodwill is economically impaired and therefore required by FASB Accounting Standards Codification Topic $350^{3}$ to be written down to implied fair value. The goodwill write-off decision is a joint outcome that is proposed by management, audited by the financial statement auditor, and monitored by the audit committee. Because "sensitive accounting estimates" are required to be discussed by the auditor with the audit committee (PCAOB 2002), it is highly likely that the annual impairment decision is monitored by the audit committee. The joint nature of the outcome, the annual timing of the assessment, and the (typical) materiality of the goodwill balance make goodwill write-off decisions a unique and important setting in which to study the effect of audit committee contextual experiences on financial reporting.

Prior research on predictors of goodwill write-off have identified a number of important factors that affect the probability of write-off including economic indicators of impairment, managerial incentives to misreport, and managerial ability to exercise discretion. After measuring and controlling for these important, higher order effects, I first test the principal question addressed by this study: whether the contextual experience of audit committee members obtained via interlocks with other firms affects write-off decisions. I test whether effects are imitative in nature (i.e., directors copy the behaviors of interlocked firms in an attempt to increase the legitimacy of their decisions), or if associations with non-impairing distressed firms also lead to greater incidence of focal

\footnotetext{
${ }^{3}$ Statement of Financial Accounting Standards No. 142 (SFAS 142) is the originally adopted standard, which is contained in Topic 350.
} 
firm write-off. I require interlock firms to be distressed to ensure that audit committee members have contextual experience with extensive impairment analyses, which is more likely when the interlocked firm is distressed. To address the relative influence of monitoring and performance contextual experience, I also estimate the difference in effects between linked audit committee members who are managers (received links) and audit committee members (neutral links) at interlocked firms.

Because financial reporting oversight is critical when management has financial incentives to manipulate financial information, I use a subsample of large firms for which I have executive compensation data to assess whether the effects of audit committee contextual experience on financial reporting vary across quartiles of managerial incentives to misreport financial information.

Audit committee members are selected from the firm's board of directors whose members are identified by nominating committees and confirmed by shareholders. Selection of audit committee members that are linked to distressed firms may, therefore, be an endogenous determination based upon observable or unobservable firm-specific characteristics. For example, nominating committees may recognize that having audit committee members with recent experience with goodwill impairment is important if they themselves are facing difficult impairment decisions. To address these endogeneity concerns, I perform two analyses related to my main results. First, I employ a two-stage Heckman model to determine if results hold when controlling for unobservable, firmspecific characteristics (e.g., Heckman 1978). I also address endogeneity concerns with 
respect to observable firm characteristics by creating a propensity score matched sample (Rosenbaum and Rubin 1983).

Finally, I provide evidence about whether audit committee member contextual experience with impairment analyses at interlocked firms is associated with decisions that appear to be in the direction of, or contrary to, economic predictions of write-off. I measure the likelihood of write-off based on economic indicators of impairment, managerial incentives to misreport, and managerial ability to exercise discretion. I then partition the sample into high and low write-off likelihood groups and address, within the high probability and low probability groups, whether audit committee experience with impairment analyses varies between firms that write off versus firms that do not write off.

I identify a 2004 - $2009^{4}$ sample that includes all firms with positive beginning of year goodwill balances included in both Compustat and BoardEx. All firms associated with the focal firm at the audit committee level in year $t-1$ are identified. At time $t, \mathrm{I}$ identify write-off decision outcomes of focal firms. Following prior research on goodwill write-off decisions, I measure proxies for economic indicators of impairment, managerial incentives to misreport, and ability of managers to exercise discretion (Francis, Hanna, and Vincent 1996; Beatty and Weber 2006; Ramanna 2008; Ramanna and Watts 2011). To differentiate between effects of my audit committee measure and other audit committee characteristics previously studied, I also control for size and financial

\footnotetext{
${ }^{4}$ My sample is limited to the post-2003 period as 2004 was the first non-implementation year in which SFAS 142 was required to be followed.
} 
expertise of the audit committee (e.g., McDaniel, Martin, and Maines 2002; Defond, Hann, and Hu 2005; Carcello, Hollingsworth, Klein, and Neal 2009; Goh 2009).

I model whether audit committee contextual experience with goodwill impairment analyses, measured as the association of a focal firm's audit committee with at least one distressed interlock firm with a goodwill balance at time $t-1$, affects the focal firm's current year write-off decision after controlling for other factors associated with writeoffs and audit committee quality. I differentiate effects of links with interlock firm audit committee members and interlock firm managers by measuring two categories of interlocks: focal firm audit committee members who are audit committee members (neutral audit committee links) and audit committee members who are CEOs or CFOs (received audit committee links) at interlocked firms. Finally, in a sub-sample of the largest firms, I estimate the effects of neutral and received interlocks with distressed firms on focal firm write-off decisions across quartiles of managerial equity-based incentives to misreport to address if effects of audit committee interlocks differ across managerial incentives to misreport.

For full-sample firms with beginning of year goodwill balances, I find that the probability of annual goodwill write-off prior to measuring interlock effects is 0.095 . The probability of write-off for firms with audit committee links to distressed firms exceeds that of firms without audit committee links by 0.024 or $28.18 \%$, consistent with a positive association between audit committee member contextual experience and focal firm goodwill write-offs. Audit committee interlocks with a firm that wrote off goodwill 
in the prior year are associated with a 0.031 marginal effect on the probability of writeoff, as compared to a 0.006 marginal effect of audit committee interlocks with distressed firms that do not write off goodwill. As to whether monitoring or performance contextual experience is more influential, I find that probability of write-off for firms with a received link (performance contextual experience) with a distressed firm exceeds that for firms without links with distressed firms by 0.039 , as compared to a statistically insignificant 0.009 marginal effect related to a neutral link (monitoring contextual experience) with a distressed firm. Overall, these results suggest that recent focal firm audit committee member experiences with impairment decisions affect focal firm financial reporting outcomes and are most influential when audit committee members are directly involved in performance of the goodwill write-off task, rather than monitoring, of interlock firm impairment decisions.

Separate regressions of goodwill write-off by quartile of incentive ratio (the proxy for managerial incentives to misreport) show the overall probability of write-off is decreasing across the incentive ratio quartiles, consistent with the exercise of accounting discretion increasing in managerial incentives to misreport. Effects of received audit committee links decline across quartiles and are only marginally significant in the second quartile. These results indicate that (a) when managerial incentives to misreport financial results are strongest, audit committee financial reporting expertise gained via associations with other firms may not provide a strong enough monitoring mechanism to deter selfinterested managers and (b) differences exist between the BoardEx sample and ExecuComp sample that may indicate that results found in previous governance studies 
using only S\&P 1500 firms may not generalize to all firms (see also Armstrong, Jagolinzer, and Larcker 2010).

In self-selection analyses, I employ a two-stage Heckman model that includes an audit committee member supply measure by geographic region, by year, as an instrumental variable in the first-stage regression. Results of the second-stage regression, including the Inverse Mills Ratio computed in the first-stage, are economically and statistically similar to primary results. My second method for addressing self-selection uses a propensity-matched subsample. Using the same first stage model as in the Heckman analysis, I calculate the propensity to have audit committee links to a distressed firm, by firm-year. I then select a treatment and control firm having the closest propensity scores and use these matched pairs in primary analyses. Results of regressions using the propensity score-matched sample are also economically and statistically similar to results previously discussed.

Finally, I estimate the propensity of firms to write off goodwill and separate firms into high and low propensity subgroups. I measure differences in the distributions of primary independent variables between write-off and no write-off firms in each of the high and low propensity subgroups. For the high propensity subgroup, the number of firms linked to a distressed firm is significantly greater for write-off firms than no writeoff firms signifying that for firms that are likely to write-off goodwill, contextual experience at the audit committee level leads to decisions in the direction of economic predictions. In the low propensity subgroup, I find significantly more links to distressed 
firms in the write-off than no write-off group, significantly more links to non-distressed firms in the no write-off group than the write-off group, and significantly more links to firms that wrote off goodwill in the prior year in the write-off group than the no-write off group. These results indicate that when likelihood of write-off is low, contextual experience with distressed firms is associated with decisions that are in the direction of and against economic predictions, providing additional evidence that forces are primarily imitative.

In summary, this dissertation provides evidence that contextual experience of audit committee members with accounting judgments and estimates, specifically goodwill write-off decisions, is associated with focal firm write-off decisions and is most important when the contextual experience is in performing the estimates as a manager at the linked firm. However, effects may only exist when managerial financial incentives to misreport are lowest, suggesting that monitoring mechanisms at the largest firms may be least effective when most needed.

The remainder of this dissertation proceeds as follows. In Chapter 2, I discuss prior research; in Chapter 3, I present hypotheses; Chapter 4 discusses data, method, and descriptive statistics; Chapter 5 presents results; Chapter 6 presents sensitivity analyses; and Chapter 7 concludes. 


\section{Chapter 2: Extant research}

\section{Governance, audit committees, and director networks}

Corporate governance structures are intended to assure that self-interested managers act in a manner consistent with long-term sustainable value while also assuring that long-term value creation is not to the detriment of other parties (Monks and Minnow 2008). Extant research has addressed, among other things, whether and how financial reporting is affected by both required and voluntary governance mechanisms such as compensation contracts, independent monitors such as auditors and audit committees, and monitoring roles of non-independent parties such as debt holders and institutional investors (for recent reviews see Armstrong, Guay, and Weber 2011 and Adams, Hermalin, and Weisbach 2010).

Prior governance research has posited that firms and their shareholders choose from a set of available governance mechanisms and given firm-specific demand for governance, select the structure best suited for the firm given their competitive and business environments (Dey 2008; Larcker, Richardson, and Tuna 2007). In choosing independent directors and financial reporting monitors, it is also likely that stakeholders optimize over a set of available audit committee member characteristics, given firmspecific demand for financial reporting and auditor oversight. ${ }^{5}$ This set of mechanisms

\footnotetext{
${ }^{5}$ While shareholders, in theory, elect directors from whom the audit committee is then selected, it is common practice for management to identify replacement candidates for departing directors. Shareholders then vote to ratify the nominations of management (Hermalin and Weisbach 1998) and the nominating committee of the board of directors. Under either scenario, new directors are likely selected based upon the same characteristics, using a different preference function. For example, shareholders might prefer
} 
includes independence and compensation of members, financial expertise, number of members, and governance or audit committee expertise, among other characteristics.

A number of studies have found mixed results on the relationships between audit committee member characteristics and financial reporting outcomes. Audit committee member characteristics include, for example, director independence (Beasley 1996; Carcello and Neal 2000; Klein 2002; Dey and Liu 2010), financial expertise (McDaniel, Martin, and Maines 2002; Farber 2005; Defond, Hann, and Hu 2005; Carcello, Hollingsworth, Klein, and Neal 2009; Dhaliwal, Naiker, and Navissi 2010), and meeting frequency (Farber 2005; Larcker et al. 2007).

The most relevant audit committee research to the current study is that regarding financial expertise. In the short number of years subsequent to the Sarbanes-Oxley Act of 2002 (SOX), a number of studies have addressed whether the type of audit committee financial expertise affects financial reporting and have found that the positive associations between financial expertise and earnings quality are driven by a subset of financial experts generally deemed to be accounting financial experts. More recently, Dhaliwal et al. (2010) presented findings that accounting expertise is positively associated with accruals quality, but that there is an optimal combination of both accounting and finance expertise on the audit committee. Similar to Dhaliwal et al. (2010), I examine whether contextual experience obtained through association with other firms affects financial reporting outcomes, and thus posit that each audit committee 
member can affect financial reporting outcomes, regardless of accounting or nonaccounting specifications.

Prior research has also examined effects of participation on multiple boards on governance quality and generally associates "busy boards," whose members serve on multiple boards, with "bad governance” (e.g., Larcker et al. 2007; Ahmed and Duellman 2007; Beasley 1996; Fich and Shivdasani 2006). However, a study limited to audit committees finds that "busy audit committee members," as measured by the number of audit committee positions held by audit committee members in other public companies, are negatively associated with auditor dismissal after the issuance of a going concern report (Carcello and Neal 2003). While they attribute this result to reputational concerns, (i.e., directors with more board seats have more to lose), the result is also consistent with contextual experience gained by participating on other audit committees enhancing director abilities in monitoring the auditor relationship.

Inter-firm learning via formal and informal networks has been a significant topic of interest in sociology and management research. Organizations become more similar over time due to isomorphism, defined as "a constraining process that forces one unit in a population to resemble other units that face the same set of environmental conditions" (Hawley 1968). Types of isomorphism include those related to regulations and standards (coercive isomorphism), the rise of professionalism (normative isomorphism), and the imitation of others due to uncertainty (mimetic isomorphism) (DiMaggio and Powell 
1983). ${ }^{6}$ In their discussion of mimetic isomorphism, DiMaggio and Powell (1983) note "uncertainty is also a powerful force that encourages imitation. When organizational technologies are poorly understood, when goals are ambiguous, or when the environment creates symbolic uncertainty, organizations may model themselves on other organizations.”

Research in management has adapted mimetic isomorphism theory to the behaviors of firms noting that through participation in networks, firms are exposed to operational practices and processes used to make decisions that affect focal firm decision making (e.g., Haunschild 1993; Haunschild 1994; Haunschild and Beckman 1998). Networks studied include industries (Fligstein 1985), localities (Galaskiewicz and Wasserman 1989), associations with professional services firms (Haunschild 1994), and common directorships.

One director network study finds that the rapid cross-sectional adoption of poison pills from 1984 - 1989 is due to interlock network diffusion (Davis 1991). Other studies find that interlocks with firms via board of director networks affect corporate acquisition activities (Haunschild 1993) and premiums paid on acquisitions (Haunschild 1994), and that heterogeneity of interlock behaviors can lead to better focal firm decisions (Beckman and Haunschild 2002). ${ }^{7}$ Additionally, a recent study in finance has found that

\footnotetext{
${ }^{6}$ In their review of alternative perspectives on corporate governance, Cohen, Krishnamoorthy, and Wright (2008) identified institutional theory as an important and under-explored theory in governance.

${ }^{7}$ Researchers in economics have termed such behaviors as herding, or informational cascades (e.g., Banerjee 1992; Bikhchandani, Hirshleifer, and Welch 1992), whereby individuals assess others as having better information and therefore follow preceding decisions, ignoring what they believe to be inferior, private information.
} 
director network interlocks also affect governance structural decisions, including board size and percentage of outsiders on the board, among others (Bouwman 2011). Similarly, ambiguity regarding how to apply required financial reporting standards and uncertainty regarding legitimacy of firm-selected methods could lead audit committee network firms to mimic financial reporting behaviors of other firms to obtain legitimacy for focal firm judgments and decisions.

The majority of accounting research regarding interlocks examines capital market effects on all network firms due to an event, such as a restatement, material weakness remediation, or the perpetration of fraud by management, at one network firm and measures investor perception of inter-firm contagion. This line of research has identified negative capital market effects on focal firms due to association with restating firms via industries (Gleason, Jenkins, and Johnson 2008) and common directorships (Chen and Goh 2010). Srinivasan (2005) finds that audit committee association with a restating firm leads to audit committee member turnover not only at the restating firm, but also on other audit committees. Such contagion effects through audit committees indicate that investors and other decision makers perceive that individual audit committee members affect firm financial reporting quality.

While investors may believe that a focal firm board interlock with a restating firm indicates that lax governance is likely at the focal firm as well, these studies do not provide evidence regarding whether the perceived association exists. Four recent studies have more directly addressed whether interlocks affect operational decisions and/or 
aggregate accounting outcomes. Bizjak, Lemmon, and Whitby (2009) find firms that are linked, via the board of directors, with firms that backdated stock options are more likely to backdate stock options themselves. "Bad" behavior, in the form of participating in abusive tax shelters, has also been shown to be more likely if the firm is associated with another firm that engaged in tax shelters, via the board of directors (Brown 2011).

Chiu et al. (2010) address whether "financial reporting behaviors are propagated through interlocking boards” and find that board of director interlocks with a restating firm are associated with lower earnings quality at the focal firm, and that in the absence of a board interlock with a restating firm, the number of board interlocks is positively associated with accrual quality. A concurrent study shows that accounting quality, as measured by accruals quality, is significantly correlated between firms that are interlocked at the director level, and more significantly at the audit committee level (Shi et al. 2011).

The current study differs from, and improves upon, these two studies in two important and distinct ways. The accruals measures used in Chiu et al. (2010) and Shi et al. (2011) are broader and noisier measures than the specific accounting estimate used in the current study, and it is therefore likely that the previous and concurrent study could be identifying associations between other firm-specific characteristics also associated with accruals measures rather than the transfer of information between firms. This dissertation addresses whether contextual experience obtained about a specific accounting decision in the prior year affects audit committee members' accounting decisions in the current year, 
a much more direct and observable association. Second, previous studies rely on samples that intersect with ExecuComp, which includes only S\&P 1500 firms. The current study's use of BoardEx data allows for a larger, more diverse sample and therefore greater ability to generalize beyond the extremely large and (arguably) better controlled firms included in the S\&P 1500 index.

My terminology of received, sent, and neutral ties is derived from the management literature, and characterizes links in a similar manner. As diagrammed in Figure 1, linked audit committee members participate in interlocked firm financial reporting either as an audit committee member (monitoring contextual experience received via neutral audit committee links, or NACL), or as a manager (performance contextual experience received via received audit committee links, or RACL). As a third interlock type, I identify focal firm CEO or CFO participation on another firm's audit committee (sent audit committee links, or SACL).

\section{Accounting judgments, accounting estimates, and managerial incentives}

Judgments are of current interest to standard setters and regulators. In 2008, the SEC’s Advisory Committee on Improvements to Financial Reporting recommended that both the SEC and Public Company Accounting Oversight Board (PCAOB) adopt policy statements to issuers and auditors, respectively, regarding the use of judgments in financial reporting (CIFiR 2008). Additionally, in 2010, the PCAOB proposed changes to the existing auditing standards regarding communications with audit committees about monitoring critical estimates made by managers (PCAOB 2010). 
Estimates in financial reporting are not new but the 2006 issuance of an accounting standard devoted entirely to appropriate methods for making fair-value estimates (SFAS 157) and the recent financial crisis, attributed by some to fair-value accounting issues, ${ }^{8}$ have served to heighten stakeholder awareness of, and demand for information regarding, judgment-related issues. ${ }^{9}$ Also, as the monetary magnitude and number of accounting standards requiring estimation increases, the degree of discretion managers are able to exercise has increased.

Research on accounting discretion has addressed whether managers use their discretion opportunistically or efficiently (Bowen, Rajgopal, and Venkatachalam 2008). Bowen et al. (2008) find that while weak governance is associated with increased accounting discretion, accounting discretion and future returns are also positively associated, which they characterize as shareholders benefiting from the accounting discretion allowed by lax governance. Another study, however, finds that managers opportunistically use the discretion allowed in goodwill impairment rules rather than convey private information about future cash flows (Ramanna and Watts 2011). Thus, there is mixed evidence whether discretion inherent in accounting estimates is used opportunistically to the betterment or detriment of stakeholders. ${ }^{10}$

\footnotetext{
${ }^{8}$ Note that contrary to this attribution, Barth and Landsman (2010) conclude that fair-value accounting had little to do with the financial crisis.

${ }^{9}$ As one example, in their 2000 annual report's use of estimates footnote, Pfizer management disclosed four categories of estimates within their annual financial statements but disclosed seventeen categories of estimates in their 2009 annual report.

${ }^{10}$ I do not attempt to reconcile this mixed evidence in this study. Rather, I provide evidence regarding audit committee monitoring of accounting estimates and leave to future research whether monitoring outcomes are efficient.
} 
In contrast to Chiu et al. (2010) and Shi et al. (2011), I estimate the impact of audit committee contextual experience regarding a specific accounting decision involving estimation and therefore judgment: goodwill impairment decisions. Discretion in the impairment decision is important because audit committee monitoring of financial reporting is most needed when managers have incentives and the ability to exercise discretion. The setting is also advantageous because the goodwill impairment assessment is likely a critical accounting estimate by firms with material goodwill balances at risk of current year impairment and is therefore required to be discussed with the audit committee under extant auditing standards (PCAOB 2010). Additionally, as all firms with recorded goodwill balances are required to perform the impairment assessment on an annual basis, a large sample of firms in which to observe associations is available and prior research has found that managerial incentives and governance mechanisms affect the goodwill write-off decision (Guler 2007).

Goodwill impairment decisions are also of recent interest to regulators. Half of the 2010 PCAOB inspection reports for the eight largest, annually inspected public accounting firms ${ }^{11}$ disclose audit deficiencies with respect to goodwill impairment analyses and testing. The PCAOB staff notes that "inspectors identified instances where auditors appeared not to have complied with PCAOB auditing standards in connection with audit areas that were significantly affected by the economic crisis, such as fair value measurements, impairment of goodwill, etc.” (PCAOB 2010). Goodwill impairment

\footnotetext{
${ }^{11}$ The largest 8 audit firms include PriceWaterhouseCoopers, Ernst and Young, Deloitte and Touche, KPMG, Grant Thornton, BDO Seidman, Crowe Chizek (now Crowe Horwath), and McGladrey and Pullen.
} 
decisions are thus an important and timely setting in which to investigate effects of audit committee contextual experience on financial reporting outcomes.

Goodwill impairment tests are to be performed by management whenever deemed necessary but at least annually, as discussed in Topic 350 of the Financial Accounting Standards Board Accounting Standards Codification (FASB 2001). These tests require two steps. First, firms must determine whether goodwill appears to be impaired by comparing the carrying amount of each reporting unit with its fair value. If book value is greater than fair value (an indicator of distress), managers must then estimate the implied fair value of goodwill by assigning the reporting unit's fair value to all identifiable assets and liabilities. The excess of the fair value of a reporting unit over the book value of net assets is the implied fair value of goodwill and if this amount exceeds the book value of goodwill, goodwill is written-down to implied fair value (ASC Section 350-20-35).

Prior studies on goodwill impairment measure the effect of a multitude of independent variables on write-off decisions in the pre-SFAS 142 period (Francis et al. 1996; Hayn and Hughes 2006), the transition period (Beatty and Weber 2006; Li, Shroff, Venkataraman, and Zhang 2010), and subsequent to the implementation of SFAS 142 (Ramanna 2008; Ramanna and Watts 2011; Li and Sloan 2009). These studies motivate the selection of control variables in the current study through their associations of goodwill write-offs with three types of factors: economic indicators of impairment, managerial incentives to misreport, and managerial ability to exercise discretion. 
In the most recent study, Ramanna and Watts (2011) address whether the lack of goodwill write-off when economic indicators of impairment are high is related to private information about future cash flows or to opportunistic behaviors. They find no evidence regarding their private information hypothesis and some evidence to show that managerial contracting and reputational motives are motivating factors not to write off goodwill. Thus, managerial incentives are important in the write-off decision, making audit committee oversight essential for unbiased reporting. The current study complements Ramanna and Watts (2011) by testing whether audit committees use monitoring or performance contextual experience gained via their associations with other firms in their monitoring of goodwill write-off decisions and whether this mechanism is effective across all levels of managerial incentives. 


\section{Chapter 3: Hypotheses}

Corporate governance is intended to address the problem of agency costs (Monks and Minnow 2008) and as a legally mandated governance mechanism, the audit committee is charged with oversight of the firm's accounting and financial reporting processes and audits of the financial statements (U.S. Congress 2002). Effective audit committees should therefore mitigate the specific agency problem of managerial selfinterest in financial reporting outcomes.

Audit committee members must be independent from the firm, other than their participation on the board of directors (U.S. Congress 2002), and therefore members of management are not permitted to be members of the audit committee. Independence is a preferred characteristic of financial reporting monitors because independence facilitates unbiased assessment of the financial position and performance of the firm. However, relative to inside directors, independence limits the amount of firm-specific information and contextual experience that the audit committee has and requires that audit committee members rely on members of management, auditors, and the audit committee member's own experiences with other firms to inform their decision making and oversight. The degree by which audit committee members rely on each of these groups and group experiences is likely a function of the managers' and auditors' incentives to misreport, or bias, financial reporting.

Through their associations with interlock firm impairment decisions, audit committee members obtain contextual experience regarding impairment analyses, and associated write-off decisions, used by other firms to implement the annual impairment 
decision requirements. This contextual experience may assist effective audit committees in monitoring focal firm impairment decisions, leading to higher quality outcomes; alternatively, attempts to gain legitimacy for their decisions may lead focal firm audit committees to simply mimic the behaviors of other firms, possibly leading to low quality outcomes.

Based upon the conflicting results of prior research that finds both "busy boards" are less effective boards and that performance on multiple audit committees, or audit committee expertise, is a "good governance” mechanism, I make no directional prediction and state my first hypothesis regarding the effect of audit committee interlocks with distressed firms in null form. However, based upon mimetic isomorphism theory, I expect that recent experience with network firms that wrote off goodwill in year $t-1$ at interlocked firms will be positively associated with focal firm write-offs in year $t^{12}$ and will be greater than associations with distressed firms that did not write off goodwill. Formally, I hypothesize that:

H1: Audit committee contextual experience with impairment decisions will have no effect on the likelihood of goodwill write-off.

H2: The likelihood of goodwill write-off is positively associated with audit committee contextual experience involving a prior-year goodwill write-off and is greater than the association between the likelihood of goodwill write-off and audit committee contextual experience with impairment decisions not involving a prior-year goodwill write-off.

\footnotetext{
${ }^{12}$ I measure interlock outcomes at time $t-1$ and focal firm decisions at time $t$ to help assure that interlock impairment decisions are made prior to focal firm decisions.
} 
Linked audit committee members can be either managers (received links) or audit committee members (neutral links) at the interlocked firm. ${ }^{13}$ I expect that the presence of a received link with a distressed firm will be more influential than the presence of a neutral link with a distressed firm because managers have more experience with interlock firm write-off decisions than part-time directors, and therefore should have more influence over audit committee members and firm management than audit committee members with monitoring contextual experience only. My third hypothesis is:

H3: The association between performance contextual experience with a distressed firm and focal firm likelihood of write-off is greater than the association between a monitoring contextual experience with a distressed firm and focal firm likelihood of write-off.

There are also competing predictions with respect to the interaction of managerial equity-based compensation and audit committee contextual experience on financial reporting outcomes. Audit committee members obtain information regarding financial reporting from managers, auditors, and other external sources such as financial reporting or audit committee experience. If audit committees are effective monitors of selfinterested managers, I expect that the effect of audit committee interlocks on impairment decisions will be increasing in managerial incentives to misreport as audit committees rely increasingly on other sources of information (rather than internal information provided by managers) to mitigate the effect of managerial self-interest. However, top managers have the ability to override internal controls and therefore allow and hide

\footnotetext{
${ }^{13}$ While I include sent links for completeness, I make no hypotheses because focal firm managers cannot be members of the focal firm audit committee.
} 
earnings management activities from monitors leading to the expectation that the effect of audit committee interlocks will be decreasing in managerial incentives to misreport. Due to these conflicting expectations, I make no directional prediction and state the fourth hypothesis in null form:

H4: The associations between audit committee interlocks and focal firm likelihood of write-off will not differ in the level of managerial incentives to misreport. 


\section{Chapter 4: Data, models, and descriptive statistics}

In this chapter, I present the data used in the study, models used to test hypotheses, and descriptive statistics regarding dependent, independent, and control variables.

\section{Data}

Using Compustat and BoardEx, ${ }^{14}$ I identify all firms that have the required financial data for at least two consecutive years from 2003 through 2009, resulting in a sample of 22,371 firm-year observations from 2004 through 2009. Because I want to assess the effect of audit committee contextual experience on all goodwill write-off decisions, rather than only when goodwill appears to be economically impaired, I include all firms with positive goodwill balances at $t-1$ and control for expected write-off. ${ }^{15}$ After deleting all observations for which data to calculate control variables is missing, eliminating firms in the financial services industry, eliminating firms without CEO or CFO tenure information in BoardEx, and eliminating firms without beginning of year goodwill balances, I obtain a final sample of 7,765 firm-year observations (2,144 distinct firms). I limit the sample to the post-2003 period because 2004 was the first nontransition year in which firms were required to assess goodwill for impairment at least annually under SFAS 142. Table 1 presents a sample selection summary and descriptive statistics of primary interlock variables by industry.

\footnotetext{
${ }^{14}$ BoardEx is a proprietary database that includes over 380,000 world-wide business leaders. It provides information regarding board of director associations, including committees on which they serve and director compensation.

${ }^{15}$ In contrast, other studies of goodwill impairment decisions limit their samples to firms for which goodwill is likely economically impaired (e.g., Beatty and Weber 2006; Ramanna and Watts 2011).
} 
To measure management's financial incentives to misreport financial results, I identify a sub-sample of firms with executive compensation data in Standard and Poor's ExecuComp database, resulting in 4,144 sub-sample firm-year observations. ExecuComp provides comprehensive compensation data on the top five officers in firms comprising the S\&P 1500 Index.

Table 2 provides descriptive statistics on all dependent, independent, and control variables, separated into write-off and no write-off firms. As shown in Table 2, for firms writing off goodwill, sub-sample firms are larger having an average market value of equity of $\$ 7.02$ billion versus full-sample $\$ 5.78$ billion. Sub-sample write-off firms are also, on average, better performers with a restricted sample ROA of 0.09 as compared to full-sample ROA of 0.06. Finally, for write-off firms, expected write-off is significantly lower in the sub-sample, where the percentage of expected write-off firms (firms with book value greater than market value of equity) is $25.5 \%$ versus $33.2 \%$ in the full sample.

\section{Dependent Variable}

For each firm-year, I create a dichotomous variable equal to 1 if the firm wrote off any goodwill in the current year, 0 otherwise. Prior goodwill impairment research estimates effects on both the decision to write-off goodwill as well as amounts of writeoff. I use a dichotomous classification because the decision to write off any positive amount is important as it acknowledges impairment significance. Also, the audit committee is likely to be involved in the write-off decision when the auditor and manager disagree with respect to whether goodwill is sufficiently impaired such that at least some 
write-off must be recorded, but less likely to be involved in the mechanical calculations of how much to write off. Firms are only required to record adjustments that are deemed material, and therefore any write-off is significant. The difficult decision in which the audit committee is likely involved is whether to write off any amount, not necessarily the amount itself. The dichotomous classification, rather than dollar amount of the write-off, should capture a meaningful degree of audit committee participation in the joint impairment decision. The average balance of goodwill for the full sample is $\$ 707.46$ million and the average write-off amount is $\$ 29.17$ million. This and other descriptive statistics, by year, are presented in Table 3.

\section{Interlock Variables}

For each of the sample firm-years identified, I use BoardEx to identify all audit committee members, the CEO, and the CFO. For each individual, I determine whether they were associated with other firms in the prior year, as either an audit committee member or manager. I require the association to be in the prior year to control for potential concerns about reverse causality and to assure that the contextual experience with interlock firms precedes the current year write-off decision with the focal firm.

The independent variables of interest measure the contextual experience of audit committee members with recent write-off decisions at interlocked firms. I identify two types of audit committee links and one type of manager link. At the focal firm I identify audit committee members who are audit committee members at other firms (neutral audit committee link, NACL) or managers at other firms (received audit committee link, 
RACL). I also combine NACL and RACL into one variable, audit committee link (ACL), which identifies any type of link at the focal firm audit committee level. I include managerial participation on other boards (sent audit committee links, SACL) as a control variable because managers attempting to make unbiased estimates may use information obtained via participation on other audit committees while performing their duties at the focal firm.

Next, I identify whether, at time $t$-1, each linked firm was distressed (having book value of equity in excess of market value of equity), and classify ACL_Distress equal to 1 if any interlock firm is distressed. I identify the write-off behavior of each interlock firm and code ACL_Impair as 1 if any of the interlock firms wrote off goodwill in the prior year, and 0 otherwise. If interlock firms were not distressed and ACL_Impair is equal to 0, I classify ACL_NoDistress equal to 1, representing audit committee interlocks to firms that are less likely to have performed extensive goodwill impairment analyses. I code ACL_DistressNoImpair equal to 1 if the focal firm has audit committee links to any distressed firms that did not write off goodwill, indicating firms which likely performed extensive impairment analyses in the prior year but chose not to write off goodwill. To address whether ACL effects differ based upon whether links are neutral or received, I code both NACL_Distress and RACL_Distress, which are equal to 1 if the firm has neutral or received links with distressed firms, respectively, 0 otherwise.

As shown in Table 3, sample firms have, on average, 2.26 links to other firms via the audit committee network from 2004 - 2009 and an average audit committee size of 
4.22 members. The percentage of audit committee members with disclosed financial expertise is $44.0 \%$ which equals 1.83 financial experts per audit committee. Among sample firms, the size of the audit committee decreased over the first decade of the $21^{\text {st }}$ century, from a mean of 4.16 members in 2000 to 4.08 members in 2009. However, the number of financial experts disclosed increased substantially, from 0.48 financial experts per audit committee in 2000 to 1.96 in 2009. The mean number of interlocks increased more than four-fold, from 0.59 interlocks per firm in 2000 to 2.41 in 2009.

\section{Control Variables}

Extant research has identified three groups of predictors of goodwill write-offs: economic indicators of impairment; managerial incentives to misreport financial information; and managerial ability to exercise discretion in goodwill impairment decisions. ${ }^{16}$ If assets are economically impaired (i.e., book values exceed market value), then a write-off is more likely but not certain. For example, when goodwill is economically impaired, managers may prefer not to record a write-off if they were involved in the acquisition that gave rise to the goodwill. However, given the complexity of a firm's financial statements, managers may have insufficient discretion to avoid write-offs. ${ }^{17}$ As complexity increases discretion also increases (Ramanna and Watts

\footnotetext{
${ }^{16}$ All control variables (except for managerial interlock control variables) are measured at time $t$ to control for current period indicators of current period write-offs.

${ }^{17}$ As an example, suppose a firm operates in one reporting unit has accumulated losses and has a market value of equity significantly below book value of equity. Even if managers have strong incentives not to write off goodwill, their ability to exercise discretion is low, and therefore the likelihood of write-off is high.
} 
2011) and greater levels of discretion have been shown to be associated with lower likelihood of write-off.

\section{Economic Indicators of Impairment}

Firms that have written off goodwill in prior years have been shown to be significantly more likely to write off goodwill in the future, even after controlling for current year indicators of impairment. I therefore control for whether a firm wrote off any goodwill in the prior year: LagDImpair is equal to 1 of the firm wrote off goodwill in the prior year, 0 otherwise; expected write-off (ExpWO) is an indicator variable equal to 1 if book value of equity exceeds market value of equity, 0 otherwise, constructed following a measure in Beatty and Weber (2006).

I also control for additional variables that may indicate good economic performance and should be negatively associated with economic impairment and thus write-offs: industry adjusted market to book ratio (IndAdjMTB), return on assets (ROA) and change in ROA (ChgROA) from time $t-1$ to time $t$. Each of these three variables is increasing in firm performance and should be associated with lower likelihood of writeoff. Following prior research I also control for one-year buy and hold return (Ret), size (Size), and leverage (Lev) and expect that firms with higher returns, are larger, and have smaller leverage ratios, respectively, are less likely to write off goodwill. 


\section{$\underline{\text { Managerial incentives to misreport }}$}

Prior research on goodwill impairment has found that managerial incentives are stronger predictors of write-off decisions than economic indicators (e.g. Beatty and Weber 2006; Ramanna and Watts 2011). Managers associated with acquisitions giving rise to goodwill balances may have reputational incentives not to write off goodwill. I control for both CEO and CFO tenure (CEOTenure and CFOTenure, respectively). I expect that the longer a manager has been with the firm, the more likely they were associated with acquisitions giving rise to goodwill balances. I therefore expect longer tenure to be associated with lower write-off likelihood. Also, concerns about possible delisting related to income requirements of major stock exchanges may provide incentives for managers to avoid goodwill write-off. I create an indicator variable, Delist, equal to 1 if the firm's shares are traded on the NASDAQ or New York Stock Exchanges, and 0 otherwise, as these exchanges have income and market capitalizationrelated delisting requirements. ${ }^{18}$

For the sub-sample of firms with management compensation data, I estimate managerial incentives using incentive ratios. Following Bergstresser and Philippon (2006), I calculate the incentive ratio as the ratio of the change in individual wealth caused by a one percent increase in stock price to total compensation (incentive ratio). For both the CEO and CFO, I measure incentive ratio as the percentage of managerial compensation that is related to a one percent change in share price. I calculate the effect

\footnotetext{
${ }^{18}$ The NYSE income requirement specifically excludes intangible asset write-offs. However, they do have market capitalization and share price threshold requirements.
} 
of a one percent change in share price on managerial holdings (ONEPCT) by multiplying a one percent change in share price at time $t$ by the total number of options and shares held by the manager at time $t$. I then divide ONEPCT by the sum of ONEPCT, salary, and bonus to create a measure of the proportion of managerial compensation that is sensitive to firm share price. I average the incentive ratios of managers by firm-year to obtain the variable AVG_IR.

\section{Managerial ability to exercise discretion}

Managers may have incentives not to write off assets and the more discretion that managers have, the more likely it is that they will be able to avoid write-off in the current period. Following Ramanna (2008) and Ramanna and Watts (2011), I use two variables to measure reporting discretion: LnSeg and UNAVal. LnSeg is measured as the natural $\log$ of the number of segments and is a proxy for the complexity of operations as well as a proxy for the number of reporting units across which managers allocate goodwill. Both are theoretically associated with the amount of managerial discretion and therefore expected to be associated with lower likelihood of write-offs. UNAVal is an estimate of the amount of net assets that management can measure with discretion and is measured as the in-sample rank of $-1 *$ [Cash + All Investments and Advances - Debt - Preferred Equity] / [Assets - Liabilities]. Because the second step of the goodwill impairment test requires estimating fair values of all assets and liabilities, I expect UNAVal, which is a measure of the proportion of net assets that are less easily verifiable, to also be associated with lower likelihood of write-off. 


\section{$\underline{\text { Audit committee quality }}$}

Prior research has identified other audit committee mechanisms that affect audit committee quality. To rule out an alternative hypothesis that other audit committee quality measures are affecting the write-off decision, I include two control variables found in prior research to be related to audit committee quality: the number of members serving on the audit committee (ACSize) and the proportion of audit committee members who are disclosed as being a financial expert (FEP). ${ }^{19}$ My independent measures are therefore intended to measure the effects of audit committee contextual experience above and beyond financial expertise as defined by the SEC.

\section{Other networks}

In an attempt to support and legitimize their preferred actions, it is likely that firms look to their auditors or other firms within their industries for guidance when making write-off decisions. Because auditors at each audit firm use a specific audit firmlevel audit methodology, use firm-standard audit software, and attend training regarding generally accepted accounting principles and auditing standards for which materials are standard within the firm, I expect write-off decisions to be associated with audit firm. To attempt to control for these other "networks" through which financial statement

\footnotetext{
${ }^{19}$ Two additional variables that have been shown to be associated with audit committee quality are independence and number of audit committee meetings. I do not control for independence because postSOX, all audit committee members are independent. I do not control for number of audit committee meetings due to data constraints. Number of meetings would require hand-collection and because a strength of this study is the large sample, I control instead for other audit committee variables shown in prior research to be associated with audit committee quality for which I have data.
} 
information, or information about write-offs, may transfer, I include both industry and audit firm fixed-effects.

Table 4 presents correlations between independent and control variables.

\section{Models}

Combined Audit Committee Links Regression

To test H1, I estimate the effects of all audit committee interlocks with distressed firms (ACL_Distress) and audit committee interlocks with non-distressed firms (ACL_NoDistress) on focal firm write-offs (DImpair) using logistic regression, controlling for other predictors of goodwill impairment and audit committee characteristics identified in prior research.

$$
\begin{aligned}
\text { DImpair }_{i, t} & =\alpha+\beta_{1} \text { ACL_ }_{-} \text {Distress }_{i, t-1}+\beta_{2} \text { ACL }_{-} \text {NoDistress }_{i, t-1}+\beta_{3} \text { SACL_ }_{-} \text {Distress }_{i, t-1} \\
& +\beta_{4} \text { SACL }_{-} \text {NoDistress }_{i, t-1}+\beta_{5} \text { ACSize }_{i, t}+\beta_{6} \text { FEP }_{i, t}+\beta_{7} \text { LagDImpair }_{i, t-1} \\
& +\beta_{8} \text { ExpWO }_{i, t}+\beta_{9} \text { IndAdjMTB }_{i, t}+\beta_{10} \text { ROA }_{i, t}+\beta_{11} \text { ChgROA }_{i, t}+\beta_{12} \text { Ret }_{i, t} \\
& +\beta_{13} \text { Size }_{i, t}+\beta_{14} \text { Lev }_{i, t}+\beta_{15} \text { Delist }_{i, t}+\beta_{16} \text { CEOTenure }_{i, t}+\beta_{17} \text { CFOTenure }_{i, t} \\
& +\beta_{18} \text { LnSeg }_{i, t}+\beta_{19} \text { UNAVal }_{i, t}+\varepsilon_{i, t}
\end{aligned}
$$

To test $\mathrm{H} 2$ regarding whether effects are driven by imitation, I separate ACL_Distress into its component parts: links with firms that wrote off goodwill in the prior year (ACL_Impair) and links with firms that were distressed but did not write off goodwill in the prior year (ACL_DistressNoImpair). 


$$
\begin{aligned}
& \text { DImpair }_{i, t}=\alpha+\beta_{1} A C L_{-} \text {NoDistress }_{i, t-1}+\beta_{2} A C L_{-} \text {Impair }_{i, t-1} \\
& +\beta_{3} \text { ACL_DistressNoImpair }_{i, t-1}+\beta_{4} \text { SACL _ }_{-} \text {Distress }_{i, t-1} \\
& +\beta_{5} \text { SACL }_{-} \text {NoDistress }_{i, t-1}+\beta_{6} \text { ACSize }_{i, t}+\beta_{7} \text { FEP }_{i, t} \\
& +\beta_{8} \text { LagDImpair }_{i, t-1}+\beta_{9} \operatorname{ExpWO}_{i, t}+\beta_{10} \text { IndAdjMTB }_{i, t} \\
& +\beta_{11} \text { ROA }_{i, t}+\beta_{12} \text { ChgROA }_{i, t}+\beta_{13} \operatorname{Ret}_{i, t}+\beta_{14} \text { Size }_{i, t} \\
& +\beta_{15} \text { Lev }_{i, t}+\beta_{16} \text { Delist }_{i, t}+\beta_{17} \text { CEOTenure }_{i, t}+\beta_{18} \text { CFOTenure }_{i, t} \\
& +\beta_{19} \operatorname{LnSeg}_{i, t}+\beta_{20} \text { UNAVal }_{i, t}+\varepsilon_{i, t}
\end{aligned}
$$

Neutral and Sent Audit Committee Links Regression

To test H3, using logistic regression I estimate the effects of both neutral and received audit committee links with a distressed firm (NACL_Distress and RACL_Distress, respectively) on focal firm write-offs (DImpair), controlling for other predictors of goodwill impairment and audit committee characteristics identified in prior research.

$$
\begin{aligned}
\text { DImpair }_{i, t} & =\alpha+\beta_{1} \text { NACL_Distress }_{i, t-1}+\beta_{2} \text { RACL_Distress }_{i, t-1} \\
& +\beta_{3} \text { SACL_Distress }_{i, t-1}+\beta_{4} \text { ACSize }_{i, t}+\beta_{5} \text { FEP }_{i, t} \\
& +\beta_{6} \text { LagDImpair }_{i, t-1}+\beta_{7} \text { ExpWO }_{i, t}+\beta_{8} \text { IndAdjMTB }_{i, t}+\beta_{9} \text { ROA }_{i, t} \\
& +\beta_{10} \text { ChgROA }_{i, t}+\beta_{11} \text { Ret }_{i, t}+\beta_{12} \text { Size }_{i, t}+\beta_{13} \text { Lev }_{i, t}+\beta_{14} \text { Delist }_{i, t} \\
& +\beta_{15} \text { CEOTenure }_{i, t}+\beta_{16} \text { CFOTenure }_{i, t}+\beta_{17} \text { LnSeg }_{i, t}+\beta_{18} \text { UNAVal }_{i, t}+\varepsilon_{i, t}
\end{aligned}
$$

Managerial Incentives Regressions

Hypothesis four addresses whether there is an interactive effect between focal firm write-offs (ACL_DImpair) and managerial incentives to misreport. In sub-sample regressions, I remove the variables in equation (3) that proxy for other managerial 
incentives to misreport and measure incentive ratios following Bergstresser and Philippon (2006). I separate firms into quartiles of a proxy for managerial incentives to misreport (AVG_IR) and using logistic regression estimate whether the effects of ACL_DImpair differ across quartiles of AVG_IR. ${ }^{20}$

$$
\begin{aligned}
\text { DImpair }_{i, t} & =\alpha+\beta_{1} N A C L_{-} \text {Distress }_{i, t-1}+\beta_{2} \text { RACL }_{-} \text {Distress }_{i, t-1} \\
& +\beta_{3} \text { SACL_Distress }_{i, t-1}+\beta_{4} \text { ACSize }_{i, t}+\beta_{5} \text { FEP }_{i, t} \\
& +\beta_{6} \text { LagDimpair }_{i, t-1}+\beta_{7} \text { ExpWO }_{i, t} \\
& +\beta_{8} \text { IndAdjMTB B B }_{i, t}+\beta_{9} \text { ROA }_{i, t}+\beta_{10} \text { ChgROA }_{i, t}+\beta_{11} \text { Ret }_{i, t}+\beta_{12} \text { Size }_{i, t} \\
& +\beta_{13} \text { Lev }_{i, t}+\beta_{14} \text { LnSeg }_{i, t}+\beta_{15} \text { UNAVal }_{i, t}+\varepsilon_{i, t}
\end{aligned}
$$

\section{Sensitivity Analyses}

\section{Tests for Endogeneity}

A common criticism of research associating corporate governance characteristics with financial reporting outcomes is that the governance characteristics are endogenously determined (possibly simultaneously with financial reporting disclosures), not random, and are likely chosen based upon the characteristics used to determine the financial reporting decisions authors look to explain. As previously noted firm directors are selected from a pool of available directors and audit committee members are selected from the full board. It would be rational for firms to select directors with goodwill impairment experience if they foresee the need for such experience by identifying which

\footnotetext{
${ }^{20}$ Alternatively, I could include AVG_IR as a control variable and interact it with ACL_DImpair. However, for ease of interpretation, I instead estimate regressions across quartiles of incentive ratio.
} 
directors have recent experience with goodwill impairment at other firms, either as managers or audit committee members.

Multiple methods have been used by others in attempts to "control" for this endogeneity problem, two of which I use here: a Heckman two-stage model (Heckman) and a propensity score matched sample (PS Match). In both the Heckman and PS Match methods the first step is to specify a model that predicts (or attempts to predict) the independent variable of interest, in this case, whether a firm is associated at the audit committee level with at least one distressed firm.

The Heckman model is intended to control for unobservable determinants of the independent variable. A measure of the unexplained portion of the dependent variable (known as the Inverse Mills Ratio or IMR) is calculated in the first stage and is used as an additional control variable in the second stage. Integral to specification of the first stage is identification of at least one instrumental variable that theoretically predicts the independent variable but should have no predictive power for the dependent variable.

The PS Match sample is used to control for observable determinants of the independent variable. In this case, the propensity to be associated with a distressed firm is modeled and a propensity score is determined for each firm. Then, for each firm that has a link to a distressed firm (the treatment firms), the firm with the closest propensity score with no link to a distressed firm is selected (the control firms).

For ease of analysis and exposition, I use the same model in the first stage of the Heckman model as used to measure propensity scores for the PS Match analysis. 
Because the variable of interest, ACL_Distress, is lagged or measured at time $t-1$, all variables predicting ACL_Distress are measured at time $t-1$ as well. I first measure the audit committee characteristic variables used in the primary analysis, ACSize and FEP, at time $t-1$ because director, and thus audit committee characteristics are likely determined jointly from a spectrum of possible characteristics (Dey 2008).

Audit committee members may be chosen for their contextual experience with goodwill impairment analyses because the focal firm either has goodwill balances or individuals nominating directors or choosing audit committee members anticipate the focal firm performing difficult impairment analyses during the director’s term. I therefore include goodwill balance (GW) and expected write-off (ExpWO) in the propensity model as well as the additional economic indicators of impairment used in the primary models previously discussed. Finally, because CEOs and CFOs likely wield power when nominating members to the board of directors and selecting audit committee members and managerial power has been shown to be increasing in tenure, I also include CEOTenure and CFOTenure as determinants.

The instrumental variable chosen for this analysis is the supply of audit committee members, by U.S. geographic region, by year. In an attempt to control costs and minimize director travel, many firms likely choose directors and thus audit committee members from the region of the country in which they are located. I first determine in which region of the United States the focal firm's headquarters are located. I classify all firms as being located in one of five regions: the Northeast, Midwest, West, Southwest, 
and Southeast. Using BoardEx, I then identify the pool, or the number of audit committee members of publicly traded firms in each region, by year. I take the natural $\log$ of the number of members in the pool to calculate my instrumental variable, LnPool. The supply of audit committee members in a specific region of the country should be associated with whether firms are interlocked with a distressed firm in a given year but should not affect firm-year specific write-off decisions.

The first-stage, or propensity model, is as follows:

$$
\begin{aligned}
\text { ACL__ }_{\text {Distress }}{ }_{i, t-1} & =\alpha+\beta_{1} \text { LnPool }_{i, t-1}+\beta_{2} \text { ACSize }_{i, t-1}+\beta_{3} \text { FEP }_{i, t-1}+\beta_{4} G W_{i, t-1} \\
& +\beta_{5} \text { ExpWO }_{i, t-1}+\beta_{6} \text { IndAdjMTB }_{i, t-1}+\beta_{7} \text { ROA }_{i, t-1}+\beta_{8} \text { ChgROA }_{i, t-1} \\
& +\beta_{9} \text { Ret }_{i, t-1}+\beta_{10} \text { Size }_{i, t-1}+\beta_{11} \text { Lev }_{i, t-1}+\beta_{12} \text { Delist }_{i, t-1} \\
& +\beta_{13} \text { CEOTenure }_{i, t-1}+\beta_{14} \text { CFOTenure }_{i, t-1}+\varepsilon_{i, t-1}
\end{aligned}
$$

For the Heckman analysis, the output of the above regression is the Inverse Mills Ratio (IMR), which is calculated and included in the second-stage regression in an attempt to control for self-selection bias. With respect to the PS Match, the output is a sample of firms that have similar likelihoods of goodwill write-off, given economic indicators of impairment, managerial incentives to misreport, and managerial ability to exercise discretion, but dissimilar incidence of links to distressed firms.

\section{Normative Analysis}

To this point, all discussion within this study has related to whether contextual experience of audit committee members affects focal firm financial reporting decisions. In this section, I now attempt to provide additional evidence regarding whether the 
amount and type of contextual experience differs across firms that are making impairment decisions that are in line with or against economic predictions. Stated differently, I provide evidence whether the effects of links to distressed firms differ when likelihood of write-off is high versus low, and whether links lead firms to make decisions that are consistent with expectations or to diverge from expectations ${ }^{21}$.

I first control for economic indicators of impairment, managerial incentives to misreport, and managerial ability to exercise discretion as well as other governance characteristic controls. I measure the propensity to write off for each firm year and rank each firm as either high or low propensity using the following logistic regression:

$$
\begin{aligned}
\text { DImpair }_{i, t}= & \alpha+\beta_{1} \text { ACSize }_{i, t}+\beta_{2} \text { FEP }_{i, t}+\beta_{3} \text { LagDImpair }_{i, t-1} \\
& +\beta_{4} \text { ExpWO }_{i, t}+\beta_{5} \text { IndAdjMTB }_{i, t}+\beta_{6} \text { ROA }_{i, t}+\beta_{7} \text { ChgROA }_{i, t}+\beta_{8} \text { Ret }_{i, t} \\
& +\beta_{9} \text { Size }_{i, t}+\beta_{10} \text { Lev }_{i, t}+\beta_{11} \text { Delist }_{i, t}+\beta_{12} \text { CEOTenure }_{i, t}+\beta_{13} \text { CFOTenure }_{i, t} \\
& +\beta_{14} \text { LnSeg }_{i, t}+\beta_{15} \text { UNAVal }_{i, t}+\varepsilon_{i, t}
\end{aligned}
$$

\footnotetext{
${ }^{21}$ Others have suggested that this should be termed as "right" and "wrong” decisions; however, since I am unable to measure the actual economic state of impairment, I simply provide evidence whether links to distressed firms are associated with decisions that are concordant or discordant with economic predictions.
} 


\section{Chapter 5: Results}

\section{Primary Analyses}

H1 predicts that the presence of audit committee interlocks with distressed firms, a proxy for audit committee contextual experience with write-off decisions at other firms, will be associated with a higher likelihood of focal firm write-off and is estimated by a logistic regression of DImpair on independent and control variables. H2 predicts that the presence of an audit committee interlock with at least one firm that wrote off goodwill in the prior year will be associated with a higher likelihood of focal firm write-off than interlocks with distressed firms that did not write off goodwill. H3 addresses whether performance contextual experience or monitoring contextual experience is associated with greater effects on focal firm financial reporting.

The results related to my first three hypotheses are presented in Table 5, which provides regression coefficients, and Table 6, which presents marginal effects. In both, column (1) includes only control variables found in prior research to be related to impairment decisions and audit committee related controls. Column (2) introduces combined audit committee link variables ACL_Distress and ACL_NoDistress, as well as two additional control variables that estimate firm management's prior-year experiences with linked firms at which they are members of the audit committee, SACL_Distress and SACL_NoDistress. Column (3) decomposes ACL_Distress into ACL_Impair, links with firms that wrote off goodwill in the prior year and ACL_DistressNoImpair, links with firms that were distressed but did not write off goodwill in the prior year. Column (4) 
presents results for the full regression, using equation 3, with neutral and received audit committee link specifications.

The logistic regression results for control variables from prior research on goodwill impairment are presented in Column (1). Most coefficients are consistent with prior research and the overall probability of write-off ${ }^{22}$ in the control variables-only regression is 0.095. While coefficients on audit committee related variables, ACSize and FEP, are in the expected directions, neither is statistically significant at conventional levels implying that neither of these characteristics significantly affects firm-specific goodwill write-off decisions.

Firms that wrote off goodwill in the prior year are much more likely to write off goodwill in the current year, with a marginal effect (the change in probability of a writeoff due to increasing the value of LagDImpair from its sample mean to one standard deviation above the sample mean, holding other variables constant at their means) of 0.170 or a $216.7 \%$ increase in probability of write-off in the current year over firms that did not write off any goodwill in the prior year. Expected write-off is also positively associated with the likelihood of write-off, with a marginal effect of 0.065 , or a $79.7 \%$ increase in probability of write-off over firms without expected write-off. Industry adjusted market-to-book ratio, ROA, change in ROA, and one-year returns are all

\footnotetext{
${ }^{22}$ The probability of write-off is calculated as $\pi(x)=e^{\beta^{\prime} X} /\left(1+e^{\beta^{\prime} X}\right)$ where $\beta^{\prime} X$ is calculated using the mean values of $X$. Changes in probability (or marginal effects) are calculated as the change in probability of write-off given a change in the independent variable, holding the other independent variables constant at their mean values. For dichotomous variables, the change in probability is calculated by changing the value from 0 to 1 , and for continuous variables by changing the value from the sample mean to one standard deviation above the sample mean.
} 
negatively associated (p-values all $<0.05$, two-sided throughout) with write-offs, with marginal effects of $-0.010,-0.011,-0.013$, and -0.043 , respectively.

With respect to managerial incentives to misreport, coefficients on Delist, CEOTenure, and CFOTenure are insignificant. Proxies for managerial ability to exercise discretion, LnSeg and UNAVal, are positive and significant, and negative and insignificant, respectively. In contrast to expectations, the marginal effect of LnSeg is 0.017 .

Column (2) presents results including ACL_Distress and ACL_NoDistress. The presence of audit committee links with distressed firms, ACL_Distress, is significantly and positively associated with focal firm write-off decisions (p-value $=0.019)$ and has a marginal effect on focal firm impairment of 0.024 , a $28.2 \%$ increase in probability of write-off over firms without audit committee links. The association via the audit committee network with only non-distressed firms, ACL_NoDistress, is not significantly associated with focal firm write-off, indicating that contextual experience with actual impairment decisions (rather than generic audit committee experience) is causing the association between linked firms and write-off decisions. A Wald Chi-square test of the equality of ACL_Distress and ACL_NoDistress finds the coefficients are marginally significantly different ( $\mathrm{p}$-value $=0.061)$, consistent with audit committee links, or contextual experience, affecting focal firm write-off decisions.

To determine if the ACL_Distress effect is due to imitation or financial reporting experience, I decompose ACL_Distress into ACL_Impair and ACL_DistressNoImpair. 
If the effect is imitative I would expect a positive coefficient on ACL_Impair and a 0 coefficient on ACL_DistressNoImpair. Results are presented in Column (3) of Tables 5 and 6. The coefficients on ACL_Impair of $0.351(\mathrm{p}$-value $=0.003)$ and ACL_DistressNoImpair of 0.072 (p-value $=0.588)$ are marginally statistically distinguishable $(\mathrm{p}$-value $=0.073)$. This result is consistent with audit committee experience with firms that previously wrote off goodwill being associated with focal firm write-offs, leading to a conclusion that the primary mechanism behind the association between contextual experience and write-offs is imitation, possibly to obtain legitimacy for their actions or to avoid scrutiny from regulators.

H3 predicts that effects depend on whether linked audit committee members are managers or audit committee members at distressed interlocked firms: To test H3 I decompose ACL_Distress into NACL_Distress and RACL_Distress. Results are presented in Column (4) of Tables 5 and 6. I find that while the presence of neutral links with distressed firms is positively associated with write-off, the coefficient is not statistically significant $(\mathrm{p}$-value $=0.259$ ) and that the association with a distressed firm, via a received audit committee interlock, is significant $(p$-value $=0.014)$ with a marginal effect on overall impairment of 0.039 , representing a $45.4 \%$ increase in the probability of write-off over firms without received audit committee links with distressed firms. The coefficients on NACL_Distress and RACL_Distress are marginally statistically different $(\mathrm{p}$-value $=0.061)$. The difference in coefficients implies that the presence of audit committee members having recent managerial experience at a firm making impairment 
decisions is more influential on focal firm reporting outcomes than experience via neutral audit committee links, consistent with H3.

H4 addresses whether relationships between audit committee links and the focal firm decision to write off goodwill vary with levels of managerial incentives to misreport. As managerial incentives increase, audit committee members should recognize the increasing risk of managerial bias and/or misstatement and may respond by relying less on information provided by managers and more on other sources of information, such as auditor-provided or audit committee network contextual experience-provided information. However, given strong managerial incentives to misreport, audit committee contextual experience gained via associations with other distressed firms facing difficult write-off decisions may not be adequate to deter self-interested financial reporting decisions by managers. Results of logistic regressions, by quartile of AVG_IR, of DImpair on independent and control variables for a sub-sample of large firms for which I have executive compensation data, are presented in Table 7 and marginal effects are presented in Table 8.

For all sub-sample firms, the coefficient on RACL_Distress is only marginally significant ( $p$-value $=0.064)$ as compared to the full sample where the coefficient is highly significant $(\mathrm{p}$-value $=0.014)$ even given that subsample firms have a higher average number of received links to distressed firms. Therefore, audit committee links are less influential on goodwill impairment decisions in the subsample of larger, S\&P 
1500 firms, leading to the conclusion that prior results using only S\&P 1500 firms may not generalize to non-S\&P 1500 firms.

In any quartile, the only ACL variable with significant effects is RACL_Distress, consistent with managers at distressed, interlocked firms having the greatest effect on focal firm write-offs. In the first quartile of AVG_IR, the overall probability of write-off is 0.191. I find that RACL_Distress is positively, but not significantly, associated with the likelihood of write-off with a marginal effect of 0.060 in the first quartile of AVG_IR. RACL_Distress is only significant in the second quartile (p-value $=0.017)$ with a marginal effect of 0.057 . No interlock variables are statistically significant in the third or fourth quartile regressions. The total probability of write-off in the first quartile is 0.191 as compared to the fourth quartile probability of write-off of 0.035 .

This decreasing probability of write-off across quartiles of increasing levels of equity-based compensation provides some evidence that opportunistic exercise of managerial discretion is increasing in levels of managerial incentives to misreport and that these incentives affect goodwill write-off decisions. The combined results are consistent with the hypothesis that when larger proportions of managerial compensation are sensitive to share price, audit committee interlocks may not provide a strong enough monitoring mechanism to mitigate managerial self-interest. 


\section{Chapter 6: Sensitivity analyses}

The corporate governance literature notes that (a) governance mechanisms are not "one size fits all" and therefore component characteristics are purposively selected as a package in response to stakeholder specific demand for governance (Dey 2008; Larcker et al. 2007) and (b) any relationship between governance and financial reporting is likely a jointly selected function of stakeholders' preferences. As it is likely that stakeholders with preferences for high quality financial reporting also have preferences for good governance, there is a concern that the omission of variables that jointly determine financial reporting and governance quality will lead to spurious results.

To address this concern I calculate a two-stage Heckman style regression and create a propensity score matched sub-sample. The first step of each analysis involves predicting the independent variable of interest. The instrumental variable chosen in the first stage regression that is not associated with the outcome variable in the second stage regression and is therefore excluded from the second stage regression is LnPool and is a measure of the supply of audit committee members in the firm's geographical region, by year. Theoretically, the size of the audit committee member pool should affect the likelihood that each audit committee member sits on other audit committees.

Additionally, I include other audit committee and firm characteristics that have been shown in prior research to be associated with corporate governance decisions. Panel A of Table 9 presents the results from the First-stage regression used in calculating the IMR and used to create propensity scores from which matches are selected. 


\section{Heckman model}

After completing the first stage regression, I use the results, by firm year, to calculate the IMR, which is then included in the Second Stage Regression. Panel B of Table 9 presents the estimation of equation (2) including the IMR. When comparing Column 2 from Table 5 and Panel B of Table 9, the pseudo r-squared increases from $19.4 \%$ to $26.5 \%$, indicating better overall model fit. Variable coefficients are both economically and statistically similar in the regression including the IMR to those in Table 5. As such, using the Heckman method for controlling for selection bias, primary results hold.

\section{Propensity score matching}

Next, again using the results of the regression presented in Table 9, Panel A, I calculate each firm's likelihood of being linked to a distressed firm at the audit committee level. I select matched pairs of firms that have the most similar propensity where one of the firms in the matched pair has at least one link to a distressed firm and one of the firms does not. Panel A of Table 10 presents the covariate balance between the treatment and control firms and indicates that across each of the predictor variables, there are not significant differences between treatment and control firms.

Panel B of Table 10 presents the estimation of equation (2) using the propensitymatched subsample of 2,850 firms. Similar to the Heckman results, the pseudo Rsquared increases significantly from the results presented in Table 5 to Table 10: from 19.5\% to $27.2 \%$, indicating better overall model fit. Again, the majority of coefficients 
are statistically and economically similar to the primary analyses. However, in the propensity score-matched subsample, the coefficient on ACL_NoDistress is also found to be positive and significant ( $\mathrm{p}$-value $=0.039$ ). This finding is consistent with the existence of a positive association between overall audit committee experience on writeoff decisions.

Normative analysis

Finally, I measure the propensity of firms to write off goodwill and separate firms into high and low propensity subgroups. I measure differences in the distributions of primary independent variables between write-off and no write-off firms in each of the high and low propensity subgroups. Table 11 presents results.

In the high propensity to write off subgroup, the number of firms linked to a distressed firm is significantly greater for write-off firms than no write-off firms, signifying that for firms that are likely to write off goodwill, contextual experience at the audit committee level leads to decisions in the direction of economic predictions. In the low propensity subgroup, I find significantly more links to distressed firms in the writeoff than no write-off group, significantly more links to non-distressed firms in the no write-off group than the write-off group, and significantly more links to firms that wrote off goodwill in the prior year in the write-off group than the no-write off group.

These results show that contextual experience with distressed firms is associated with decisions both in the direction of and against economic predictions and provide 
further evidence that imitation of other firms appears to be the primary cause of the association between linked and focal firm financial reporting decisions. 


\section{Chapter 7: Conclusion}

Real-world corporate governance effectiveness arises from formal, coercive mechanisms, such as independence and financial expertise, imposed by law and stock exchanges as well as from informal, voluntary elements such as networks of audit committee members. To understand the potential of how corporate governance fulfills intended roles, it is important to understand both the imposed and voluntary aspects as well as their interaction. In this dissertation, I address whether audit committee member oversight roles are influenced by their own contextual experiences with financial reporting decisions at other firms as audit committee members and managers. I also address whether the effects of contextual experiences differ across levels of managerial incentives to misreport.

I find the presence of audit committee links to distressed firms is significantly associated with goodwill write-offs. Additionally, the incidence of goodwill write-off at interlocked firms in the prior year is found to be positively associated with focal firm write-off decisions; however, the association with distressed firms that did not write off goodwill in the prior year is not associated with focal firm write-offs. The effect of having an audit committee member in a managerial role at a distressed, interlocked firm in the prior year is significantly greater than the effect of having a linked audit committee member participate on the audit committee of a distressed firm. These associations are consistent with audit committee members learning acceptable impairment assessment and implementation methodologies at interlocked firms and using that knowledge in 
monitoring the application of mandated financial reporting standards at focal firms. Results suggest that imitation of other firms' decisions occurs, likely to gain legitimacy for focal firm actions or to avoid regulatory scrutiny.

For a sub-sample of firms with executive compensation data, I address whether the effect of interlocks varies across managerial incentives to misreport. I find that the total probability of write-off is decreasing in the proxy for managerial incentives to misreport and received audit committee interlock variables are significant only in the second quartile of incentive ratio. Results indicate that performance contextual experience has the greatest audit committee member effect on focal firm impairment decisions. However, when strong managerial incentives to misreport are present at large firms, expertise gained from interactions with other firms, even in the performance of the estimates, may not be an adequate deterrent for self-interested managers. 


\section{Figures and Tables}

FIGURE 1

Contextual Experience Obtained through Audit Committee Links

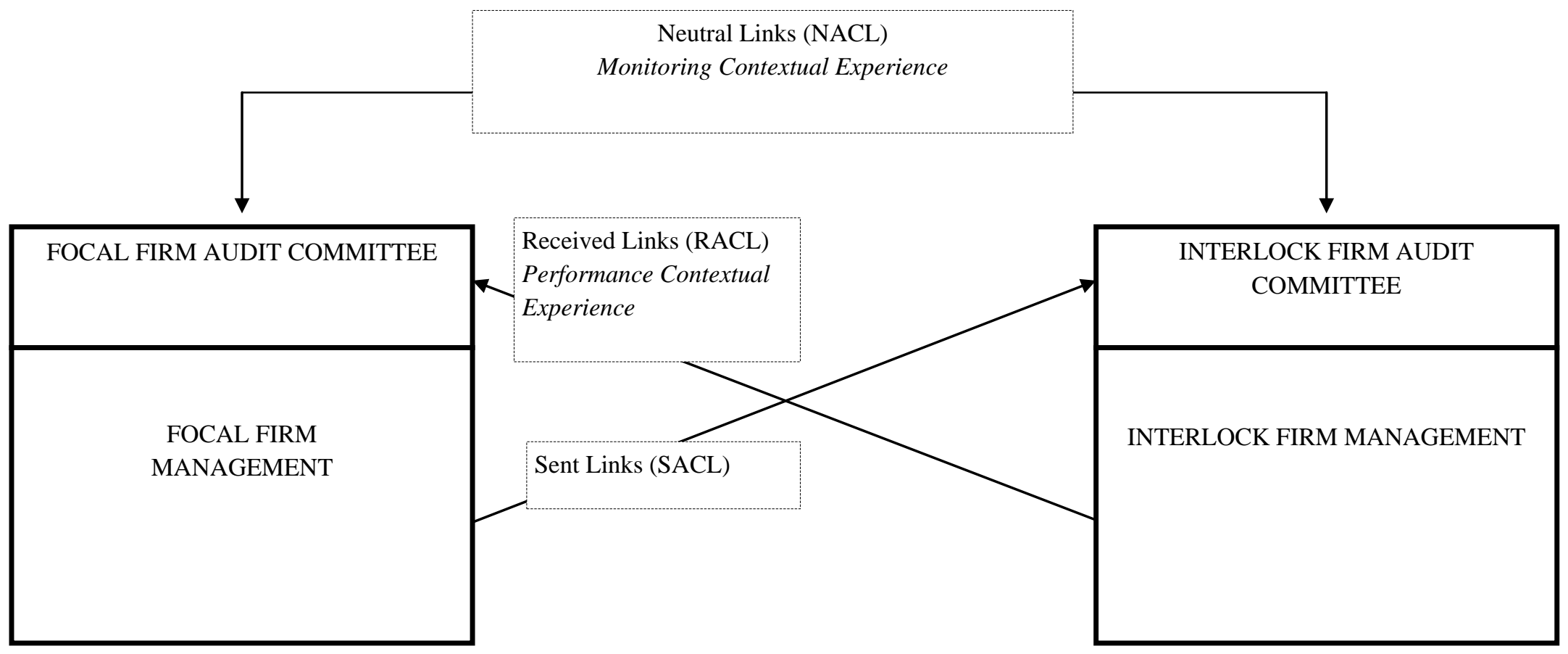

Linked audit committee members participate in interlocked firm financial reporting either as an audit committee member (neutral audit committee links, or NACL), or as a manager (received audit committee links, or RACL). As a third interlock type, I identify focal firm CEO or CFO participation on another firm's audit committee (sent audit committee links, or SACL). 
TABLE 1

Sample Selection and Industry Summary

Panel A: Sample selection

Firm-years

U.S. Firm-years on BoardEx 2004 - 2009

50,752

Less

Firm-years without Compustat data

22,371

Firm-years missing information to calculate control variables

Firm-years in the financial services industry

3,826

Firm-years missing CEO or CFO tenure information

4,955

Firm-years without positive beginning of year goodwill balances

$\underline{3,838}$

Final Full-Sample

$\underline{7,765}$

Sub-sample with ExecuComp Data

$\underline{\underline{4,144}}$

Panel B: Dependent and Independent Variables by Industry - 2004 - 2009

\begin{tabular}{rr|r|rrrr}
\hline \multicolumn{1}{c}{$\begin{array}{l}\text { 2 digit } \\
\text { SIC }\end{array}$} & Number & $\begin{array}{c}\text { Dependent } \\
\text { Variable } \\
\text { DImpair }\end{array}$ & ACL & NACL & RACL & SACL \\
\hline & & & & & & \\
10 & 339 & 0.165 & 0.802 & 0.743 & 0.230 & 0.248 \\
20 & 1,251 & 0.147 & 0.789 & 0.755 & 0.259 & 0.249 \\
30 & 2,671 & 0.151 & 0.778 & 0.718 & 0.277 & 0.205 \\
40 & 521 & 0.186 & 0.720 & 0.670 & 0.213 & 0.184 \\
50 & 932 & 0.137 & 0.777 & 0.723 & 0.222 & 0.188 \\
60 & 1,584 & 0.110 & 0.496 & 0.475 & 0.131 & 0.107 \\
70 & 1,528 & 0.120 & 0.768 & 0.725 & 0.198 & 0.190 \\
80 & 496 & 0.107 & 0.772 & 0.724 & 0.194 & 0.147 \\
90 & 27 & 0.000 & 0.741 & 0.741 & 0.444 & 0.222 \\
\hline
\end{tabular}

Amounts presented are means. DImpair $=1$ if the firm wrote off any amount of goodwill in year $t$, 0 otherwise. ACL $=1$ if the firm has at least one interlock, 0 otherwise. NACL $=1$ if the focal firm audit committee has at least one link with another firm at the audit committee level, 0 otherwise. RACL $=1$ if at least one focal firm audit committee member is a manager at another firm, 0 otherwise. SACL $=1$ if at least one focal firm manager participates on another firm's audit committee, 0 otherwise. 
TABLE 2

Summary Statistics of Independent and Control Variables

\begin{tabular}{|c|c|c|c|c|c|c|c|c|c|c|}
\hline & \multicolumn{5}{|c|}{ Write-off Firms } & \multicolumn{5}{|c|}{ No Write-off Firms } \\
\hline & Mean & StdDev & Q1 & Med & Q3 & Mean & StdDev & Q1 & Med & Q3 \\
\hline \multicolumn{11}{|l|}{ ACL_Distress } \\
\hline Full Sample & 0.282 & 0.450 & 0.000 & 0.000 & 1.000 & 0.206 & 0.404 & 0.000 & 0.000 & 0.000 \\
\hline Restricted Sample & 0.361 & 0.481 & 0.000 & 0.000 & 1.000 & 0.259 & 0.438 & 0.000 & 0.000 & 1.000 \\
\hline \multicolumn{11}{|l|}{ ACL_NoDistress } \\
\hline Full Sample & 0.513 & 0.500 & 0.000 & 1.000 & 1.000 & 0.565 & 0.496 & 0.000 & 1.000 & 1.000 \\
\hline Restricted Sample & 0.529 & 0.500 & 0.000 & 1.000 & 1.000 & 0.608 & 0.488 & 0.000 & 1.000 & 1.000 \\
\hline \multicolumn{11}{|l|}{ ACL_Impair } \\
\hline Full Sample & 0.198 & 0.399 & 0.000 & 0.000 & 0.000 & 0.136 & 0.343 & 0.000 & 0.000 & 0.000 \\
\hline Restricted Sample & 0.255 & 0.437 & 0.000 & 0.000 & 1.000 & 0.178 & 0.382 & 0.000 & 0.000 & 0.000 \\
\hline \multicolumn{11}{|l|}{ ACL_DistressNoImpair } \\
\hline Full Sample & 0.117 & 0.321 & 0.000 & 0.000 & 0.000 & 0.087 & 0.282 & 0.000 & 0.000 & 0.000 \\
\hline Restricted Sample & 0.149 & 0.356 & 0.000 & 0.000 & 0.000 & 0.106 & 0.307 & 0.000 & 0.000 & 0.000 \\
\hline \multicolumn{11}{|l|}{ NACL_Distress } \\
\hline Full Sample & 0.241 & 0.428 & 0.000 & 0.000 & 0.000 & 0.186 & 0.389 & 0.000 & 0.000 & 0.000 \\
\hline Restricted Sample & 0.308 & 0.462 & 0.000 & 0.000 & 1.000 & 0.236 & 0.424 & 0.000 & 0.000 & 0.000 \\
\hline \multicolumn{11}{|l|}{ RACL_Distress } \\
\hline Full Sample & 0.058 & 0.234 & 0.000 & 0.000 & 0.000 & 0.029 & 0.169 & 0.000 & 0.000 & 0.000 \\
\hline Restricted Sample & 0.080 & 0.462 & 0.000 & 0.000 & 1.000 & 0.037 & 0.190 & 0.000 & 0.000 & 0.000 \\
\hline \multicolumn{11}{|l|}{ SACL_Distress } \\
\hline Full Sample & 0.034 & 0.182 & 0.000 & 0.000 & 0.000 & 0.032 & 0.175 & 0.000 & 0.000 & 0.000 \\
\hline Restricted Sample & 0.047 & 0.212 & 0.000 & 0.000 & 0.000 & 0.046 & 0.209 & 0.000 & 0.000 & 0.000 \\
\hline \multicolumn{11}{|l|}{ SACL_NoDistress } \\
\hline Full Sample & 0.170 & 0.376 & 0.000 & 0.000 & 0.000 & 0.173 & 0.378 & 0.000 & 0.000 & 0.000 \\
\hline Restricted Sample & 0.236 & 0.425 & 0.000 & 0.000 & 0.000 & 0.238 & 0.426 & 0.000 & 0.000 & 0.000 \\
\hline \multicolumn{11}{|l|}{ ACSize } \\
\hline Full Sample & 4.222 & 1.521 & 3.000 & 4.000 & 5.000 & 4.217 & 1.588 & 3.000 & 4.000 & 5.000 \\
\hline Restricted Sample & 4.614 & 1.604 & 4.000 & 4.000 & 5.000 & 4.486 & 1.652 & 3.000 & 4.000 & 5.000 \\
\hline \multicolumn{11}{|l|}{ FEP } \\
\hline Full Sample & 0.450 & 0.265 & 0.250 & 0.333 & 0.600 & 0.438 & 0.264 & 0.250 & 0.333 & 0.600 \\
\hline Restricted Sample & 0.475 & 0.275 & 0.250 & 0.400 & 0.668 & 0.475 & 0.281 & 0.250 & 0.333 & 0.667 \\
\hline
\end{tabular}


TABLE 2

Summary Statistics of Independent and Control Variables (Continued)

\begin{tabular}{|c|c|c|c|c|c|c|c|c|c|c|}
\hline & Mean & StdDev & Q1 & Med & Q3 & Mean & StdDev & Q1 & Med & Q3 \\
\hline \multicolumn{11}{|l|}{ LagDImpair } \\
\hline Full Sample & 0.244 & 0.430 & 0.000 & 0.000 & 0.000 & 0.068 & 0.252 & 0.000 & 0.000 & 0.000 \\
\hline Restricted Sample & 0.266 & 0.442 & 0.000 & 0.000 & 1.000 & 0.073 & 0.261 & 0.000 & 0.000 & 0.000 \\
\hline \multicolumn{11}{|l|}{ ExpWO } \\
\hline Full Sample & 0.332 & 0.471 & 0.000 & 0.000 & 1.000 & 0.087 & 0.282 & 0.000 & 0.000 & 0.000 \\
\hline Restricted Sample & 0.255 & 0.437 & 0.000 & 0.000 & 1.000 & 0.049 & 0.216 & 0.000 & 0.000 & 0.000 \\
\hline \multicolumn{11}{|l|}{ IndAdjMTB } \\
\hline Full Sample & -0.936 & 2.749 & -1.749 & -1.189 & -0.590 & 0.004 & 3.269 & -1.447 & -0.627 & 0.563 \\
\hline Restricted Sample & -0.789 & 2.730 & -1.655 & -1.027 & -0.345 & 0.220 & 3.262 & -1.250 & -0.404 & 0.869 \\
\hline \multicolumn{11}{|l|}{$R O A$} \\
\hline Full Sample & 0.056 & 0.145 & 0.011 & 0.076 & 0.129 & 0.115 & 0.143 & 0.072 & 0.125 & 0.180 \\
\hline Restricted Sample & 0.094 & 0.099 & 0.050 & 0.095 & 0.141 & 0.151 & 0.102 & 0.100 & 0.144 & 0.197 \\
\hline \multicolumn{11}{|l|}{ ChgROA } \\
\hline Full Sample & -0.028 & 0.084 & -0.050 & -0.015 & 0.010 & 0.001 & 0.085 & -0.025 & 0.001 & 0.024 \\
\hline Restricted Sample & -0.023 & 0.066 & -0.043 & -0.014 & 0.010 & -0.001 & 0.059 & -0.020 & 0.001 & 0.019 \\
\hline \multicolumn{11}{|l|}{ Ret } \\
\hline Full Sample & -0.231 & 0.513 & -0.595 & -0.322 & 0.029 & 0.132 & 0.574 & -0.207 & 0.048 & 0.341 \\
\hline Restricted Sample & -0.132 & 0.511 & -0.485 & -0.197 & 0.136 & 0.135 & 0.462 & -0.148 & 0.081 & 0.332 \\
\hline \multicolumn{11}{|l|}{ Size } \\
\hline Full Sample & 5.780 & 2.051 & 4.314 & 5.780 & 7.177 & 6.510 & 1.919 & 5.205 & 6.528 & 7.774 \\
\hline Restricted Sample & 7.017 & 1.666 & 5.898 & 6.917 & 8.168 & 7.624 & 1.480 & 6.582 & 7.505 & 8.527 \\
\hline \multicolumn{11}{|l|}{ Lev } \\
\hline Full Sample & 1.196 & 2.434 & 0.075 & 0.362 & 1.007 & 0.377 & 0.956 & 0.008 & 0.131 & 0.354 \\
\hline Restricted Sample & 1.061 & 2.210 & 0.106 & 0.366 & 0.883 & 0.306 & 0.768 & 0.022 & 0.141 & 0.328 \\
\hline \multicolumn{11}{|l|}{ Delist } \\
\hline Full Sample & 0.873 & 0.334 & 1.000 & 1.000 & 1.000 & 0.914 & 0.281 & 1.000 & 1.000 & 1.000 \\
\hline Restricted Sample & 0.949 & 0.220 & 1.000 & 1.000 & 1.000 & 0.979 & 0.145 & 1.000 & 1.000 & 1.000 \\
\hline \multicolumn{11}{|l|}{ CEOTenure } \\
\hline Full Sample & 6.908 & 7.142 & 1.871 & 4.516 & 9.829 & 7.440 & 7.102 & 2.411 & 5.315 & 9.912 \\
\hline Restricted Sample & 6.576 & 6.975 & 1.843 & 4.018 & 9.082 & 7.244 & 7.120 & 2.434 & 4.998 & 9.082 \\
\hline \multicolumn{11}{|l|}{ CFOTenure } \\
\hline Full Sample & 4.421 & 4.455 & 1.188 & 2.959 & 6.082 & 4.864 & 4.372 & 1.641 & 3.669 & 6.831 \\
\hline Restricted Sample & 4.495 & 4.392 & 1.300 & 3.107 & 6.337 & 5.036 & 4.371 & 1.751 & 3.981 & 6.997 \\
\hline
\end{tabular}


TABLE 2

Summary Statistics of Independent and Control Variables (Continued)

\begin{tabular}{|c|c|c|c|c|c|c|c|c|c|c|}
\hline & \multicolumn{5}{|c|}{ Write-off Firms } & \multicolumn{5}{|c|}{ No Write-off Firms } \\
\hline & Mean & StdDev & Q1 & Med & Q3 & Mean & StdDev & Q1 & Med & Q3 \\
\hline $\begin{array}{l}A V G_{-} I R \\
\text { Full Sample }\end{array}$ & & & & & & & & & & \\
\hline $\begin{array}{l}\text { Restricted Sample } \\
\text { LnSeg }\end{array}$ & 0.163 & 0.147 & 0.053 & 0.119 & 0.226 & 0.238 & 0.179 & 0.108 & 0.193 & 0.324 \\
\hline Full Sample & 0.783 & 0.720 & 0.000 & 1.099 & 1.386 & 0.685 & 0.720 & 0.000 & 0.693 & 1.386 \\
\hline $\begin{array}{l}\text { Restricted Sample } \\
\text { UNAVal }\end{array}$ & 0.861 & 0.765 & 0.000 & 1.099 & 1.609 & 0.786 & 0.754 & 0.000 & 1.099 & 1.386 \\
\hline Full Sample & -1.510 & 56.945 & -0.234 & 0.222 & 0.881 & 0.155 & 9.392 & -0.348 & 0.053 & 0.509 \\
\hline Restricted Sample & -0.869 & 39.699 & -0.203 & 0.285 & 0.844 & 0.253 & 5.620 & -0.288 & 0.098 & 0.509 \\
\hline
\end{tabular}

ACL_Distress $=1$ if the firm has at least one audit committee member that is an audit committee member or manager at a distressed interlock firm, 0 otherwise. ACL_NoDistress = 1 if the firm has audit committee members who participate only on audit committees or are managers of non-distressed interlock firms, 0 otherwise. ACL_Impair $=1$ if the firm has at least one audit committee member that is an audit committee member or manager at a firm that wrote off goodwill in the prior year, 0 otherwise. ACL_DistressNoImpair $=1$ if the firm has at least one audit committee member that is an audit committee member or manager at a distressed interlock firm that did not write off goodwill in the prior year, 0 otherwise. NACL_Distress $=1$ if the firm has at least one audit committee member that is an audit committee member at a distressed interlock firm, 0 otherwise. RACL_Distress $=1$ if the firm has at least one audit committee member that is a manager at a distressed interlock firm, 0 otherwise. SACL_Distress $=1$ if the firm's CEO or CFO is an audit committee member at a distressed interlock firm, 0 otherwise. SACL_NoDistress $=1$ if the CEO or CFO participates only on audit committees of non-distressed interlock firms. ACSize $=$ the number of audit committee members at time $t$. FEP $=$ the proportion of audit committee members that are disclosed as being financial experts. ExpWO $=1$ if market value of equity is less than book value of equity at time $t, 0$ otherwise. LagDImpair $=1$ if the firm wrote off goodwill in the prior year, 0 otherwise. IndAdjMTB = firm ratio of market value of equity to book value of equity, adjusted by the mean value of the market to book ratio for the firm's 2 digit SIC code. ROA = earnings before interest, depreciation and taxes divided by average total assets. ChgROA $=$ ROA at time $t$ less ROA at time $t-1$. Ret $=12$ month buy and hold return during year $t$. Size $=$ market value of equity. Lev $=$ total current and long term debt all divided by market value of equity. Delist $=1$ if the firm's shares are traded on the NASDAQ or NYSE, 0 otherwise. CEOTenure $=$ the number of years the CEO has held his current position. CFOTenure = the number of years the CFO has held her position. AVG_IR is equal to the firm-year mean incentive ratio for the CEO and CFO. LnSeg = the natural log of the number of disclosed segments. UNAVal $=-1 *$ [Cash + All Investments and Advances - Debt - Preferred Equity] $/$ [Assets - Liabilities]. 
TABLE 3

Selected Descriptive Statistics by Year

\begin{tabular}{|c|c|c|c|c|c|c|c|c|c|c|c|}
\hline & 2000 & 2001 & 2002 & 2003 & 2004 & 2005 & 2006 & 2007 & 2008 & 2009 & $\begin{array}{c}\text { Avg } \\
04-09\end{array}$ \\
\hline ACLNum & 0.588 & 1.384 & 1.799 & 1.532 & 1.945 & 2.124 & 2.265 & 2.332 & 2.506 & 2.407 & 2.257 \\
\hline$A C L$ & 0.377 & 0.641 & 0.711 & 0.646 & 0.726 & 0.758 & 0.782 & 0.790 & 0.795 & 0.802 & 0.775 \\
\hline ACL_Distress & 0.010 & 0.102 & 0.137 & 0.153 & 0.153 & 0.164 & 0.193 & 0.177 & 0.253 & 0.408 & 0.216 \\
\hline ACL_Impair & 0.000 & 0.033 & 0.067 & 0.092 & 0.104 & 0.108 & 0.119 & 0.114 & 0.165 & 0.301 & 0.145 \\
\hline NACLNum & 0.239 & 1.434 & 1.880 & 1.594 & 1.976 & 2.136 & 2.252 & 2.263 & 2.411 & 2.213 & 2.209 \\
\hline$N A C L$ & 0.128 & 0.530 & 0.634 & 0.561 & 0.664 & 0.707 & 0.724 & 0.741 & 0.758 & 0.758 & 0.724 \\
\hline NACL_Distress & 0.000 & 0.088 & 0.116 & 0.133 & 0.146 & 0.140 & 0.179 & 0.150 & 0.211 & 0.385 & 0.194 \\
\hline RACLÑum & 0.405 & 0.309 & 0.326 & 0.295 & 0.298 & 0.294 & 0.289 & 0.286 & 0.259 & 0.288 & 0.286 \\
\hline$R A C L$ & 0.318 & 0.271 & 0.259 & 0.245 & 0.250 & 0.249 & 0.242 & 0.239 & 0.222 & 0.245 & 0.241 \\
\hline RACL_Distress & 0.010 & 0.019 & 0.023 & 0.025 & 0.013 & 0.029 & 0.024 & 0.031 & 0.063 & 0.045 & 0.033 \\
\hline SACLNum & 0.038 & 0.202 & 0.243 & 0.199 & 0.251 & 0.267 & 0.271 & 0.275 & 0.272 & 0.283 & 0.270 \\
\hline$S A C L$ & 0.038 & 0.171 & 0.201 & 0.148 & 0.184 & 0.200 & 0.207 & 0.205 & 0.213 & 0.220 & 0.204 \\
\hline SACL_Distress & 0.000 & 0.014 & 0.012 & 0.027 & 0.028 & 0.023 & 0.021 & 0.028 & 0.031 & 0.070 & 0.032 \\
\hline ACSize & 4.159 & 4.682 & 4.748 & 4.390 & 4.290 & 4.364 & 4.268 & 4.166 & 4.098 & 4.081 & 4.218 \\
\hline FEP & 0.123 & 0.127 & 0.175 & 0.315 & 0.378 & 0.408 & 0.445 & 0.458 & 0.470 & 0.489 & 0.440 \\
\hline FENum & 0.484 & 0.558 & 0.778 & 1.331 & 1.573 & 1.764 & 1.880 & 1.895 & 1.905 & 1.964 & 1.827 \\
\hline Goodwill & 852.837 & 722.515 & 637.120 & 619.297 & 552.622 & 560.406 & 662.979 & 718.718 & 814.548 & 1012.780 & 707.461 \\
\hline DImpair & 0.035 & 0.061 & 0.106 & 0.104 & 0.069 & 0.093 & 0.099 & 0.106 & 0.275 & 0.246 & 0.142 \\
\hline Impair & 23.943 & 2.807 & 17.634 & 12.816 & 21.421 & 11.154 & 6.663 & 35.740 & 63.258 & 42.813 & 29.169 \\
\hline LagDImpair & 0.000 & 0.030 & 0.069 & 0.055 & 0.078 & 0.057 & 0.084 & 0.089 & 0.085 & 0.189 & 0.093 \\
\hline ExpWO & 0.145 & 0.077 & 0.134 & 0.079 & 0.053 & 0.058 & 0.055 & 0.104 & 0.290 & 0.202 & 0.122 \\
\hline Delist & 0.955 & 0.956 & 0.954 & 0.899 & 0.895 & 0.887 & 0.892 & 0.899 & 0.935 & 0.951 & 0.908 \\
\hline CEOTenure & 6.983 & 6.821 & 7.154 & 7.330 & 7.420 & 7.430 & 7.260 & 7.271 & 7.371 & 7.471 & 7.364 \\
\hline CFOTenure & 4.238 & 4.639 & 4.581 & 4.590 & 4.792 & 4.732 & 4.684 & 4.793 & 4.760 & 5.130 & 4.801 \\
\hline$A V G \_I R$ & 0.287 & 0.304 & 0.263 & 0.284 & 0.266 & 0.247 & 0.227 & 0.238 & 0.179 & 0.205 & 0.228 \\
\hline Full Sample N & 289 & 362 & 432 & 1,013 & 1,272 & 1,394 & 1,399 & 1,407 & 1,270 & 1,023 & 7,765 \\
\hline ЕхесиСотр $N$ & 226 & 273 & 310 & 572 & 671 & 718 & 746 & 757 & 695 & 557 & 4,144 \\
\hline
\end{tabular}


TABLE 3

Selected Descriptive Statistics by Year (Continued)

All amounts (except N's) are means. ACLNum = the number of audit committee links at $t-1$. ACL $=1$ if the firm has at least one interlock, 0 otherwise.

ACL_Distress $=1$ if the firm has at least one audit committee member that is an audit committee member or manager at a distressed interlock firm, 0 otherwise.

ACL_Impair $=1$ if the focal firm was interlocked at time $t-1$ to at least one firm that wrote off goodwill, 0 otherwise. NACLNum is equal to the number of neutral audit committee links at $t-1$. NACL $=1$ if the focal firm audit committee has at least one link with another firm at the audit committee level, 0 otherwise. NACL_Distress $=1$ if the firm has at least one audit committee member that is an audit committee member at a distressed interlock firm, 0 otherwise. RACLNum is equal to the number of received audit committee links at $t-1$. RACL $=1$ if at least one focal firm audit committee member is a manager at another firm, 0 otherwise. RACL_Distress $=1$ if the firm has at least one audit committee member that is a manager at a distressed interlock firm, 0 otherwise. SACLNum is equal to the number of sent audit committee links. SACL $=1$ if at least one focal firm manager participates on another firm's audit committee, 0 otherwise. SACL_Distress $=1$ if the firm's CEO or CFO is an audit committee member at a distressed interlock firm, 0 otherwise. ACSize $=$ the number of audit committee members at time $t$. FEP $=$ the proportion of audit committee members that are disclosed as being financial experts. FENum is the number of audit committee members that are disclosed as being financial experts. Goodwill $=$ the total amount of recorded goodwill at time $t$. DImpair $=1$ if the firm wrote off any amount of goodwill in year t, 0 otherwise. Impair $=$ the amount of goodwill written off at time $t$. LagDImpair $=1$ if the firm wrote off goodwill in the prior year, 0 otherwise. ExpWO $=1$ if market value of equity is less than book value of equity at time $t, 0$ otherwise. Delist $=1$ if the firm's shares are traded on the NASDAQ or NYSE, 0 otherwise. CEOTenure $=$ the number of years the CEO has held his current position. CFOTenure $=$ the number of years the CFO has held her position. AVG_IR $=$ the firm-year mean incentive ratio for the CEO and CFO. 
TABLE 4

Correlations

\begin{tabular}{|c|c|c|c|c|c|c|c|c|c|c|c|c|c|c|c|c|c|c|c|}
\hline & & 1 & 2 & 3 & 4 & 5 & 6 & 7 & 8 & 9 & 10 & 11 & 12 & 13 & 14 & 15 & 16 & 17 & 18 \\
\hline ACL_Distress & 1 & -- & 0.06 & 0.10 & 0.06 & 0.08 & -0.01 & -0.01 & 0.02 & -0.02 & -0.02 & 0.17 & 0.04 & 0.08 & -0.07 & -0.04 & -0.06 & 0.03 & 0.00 \\
\hline SACL__Distress & 2 & 0.06 & -- & 0.04 & 0.03 & 0.03 & -0.03 & 0.02 & 0.00 & 0.01 & 0.00 & 0.10 & -0.01 & 0.01 & 0.00 & 0.03 & 0.02 & 0.03 & 0.00 \\
\hline ACSize & 3 & 0.13 & 0.05 & -- & -0.07 & 0.03 & -0.05 & 0.03 & 0.05 & 0.00 & 0.00 & 0.23 & 0.00 & 0.04 & -0.09 & -0.03 & -0.01 & 0.09 & -0.01 \\
\hline FEP & 4 & 0.04 & 0.01 & -0.18 & -- & 0.03 & -0.03 & 0.04 & 0.07 & -0.02 & -0.02 & 0.18 & 0.01 & 0.06 & -0.04 & -0.01 & 0.01 & 0.03 & 0.02 \\
\hline LagDImpair & 5 & 0.08 & 0.03 & 0.03 & 0.03 & -- & 0.08 & -0.05 & -0.07 & 0.02 & 0.03 & -0.03 & 0.12 & -0.02 & -0.05 & -0.04 & -0.08 & 0.07 & 0.01 \\
\hline ExpWO & 6 & -0.01 & -0.03 & -0.05 & -0.02 & 0.08 & -- & -0.19 & -0.15 & -0.11 & -0.27 & -0.32 & 0.28 & -0.11 & 0.01 & 0.00 & -0.20 & 0.01 & 0.01 \\
\hline IndAdjMTB & 7 & 0.02 & 0.03 & 0.01 & 0.06 & -0.08 & -0.37 & -- & 0.13 & 0.08 & 0.18 & 0.21 & -0.13 & 0.04 & -0.02 & 0.01 & 0.21 & -0.07 & 0.15 \\
\hline ChgROA & 9 & -0.03 & -0.00 & 0.00 & -0.03 & 0.02 & -0.14 & 0.14 & 0.23 & -- & 0.29 & 0.04 & -0.03 & 0.03 & -0.01 & -0.02 & 0.02 & 0.00 & 0.00 \\
\hline Ret & 10 & -0.01 & 0.01 & 0.03 & -0.03 & 0.01 & -0.34 & 0.29 & 0.27 & 0.32 & -- & 0.17 & -0.20 & 0.08 & 0.02 & 0.02 & 0.16 & 0.03 & 0.02 \\
\hline Size & 11 & 0.17 & 0.11 & 0.28 & 0.13 & -0.03 & -0.31 & 0.35 & 0.43 & 0.06 & 0.27 & -- & -0.18 & 0.35 & -0.05 & 0.02 & 0.46 & 0.17 & 0.01 \\
\hline Lev & 12 & 0.08 & 0.04 & 0.12 & 0.03 & 0.11 & 0.26 & -0.26 & -0.10 & -0.08 & -0.17 & 0.01 & -- & -0.14 & -0.02 & -0.01 & -0.17 & -0.01 & -0.05 \\
\hline Delist & 13 & 0.08 & 0.01 & 0.06 & 0.04 & -0.02 & -0.11 & 0.12 & 0.22 & 0.04 & 0.12 & 0.34 & -0.09 & -- & 0.00 & 0.00 & 0.08 & 0.06 & 0.02 \\
\hline CEOTenure & 14 & -0.06 & 0.00 & -0.12 & -0.01 & -0.06 & 0.00 & 0.01 & 0.07 & 0.00 & 0.05 & -0.03 & -0.03 & 0.03 & -- & 0.24 & 0.28 & 0.01 & 0.01 \\
\hline CFOTenure & 15 & -0.04 & 0.04 & -0.02 & -0.03 & -0.06 & -0.02 & 0.05 & 0.13 & -0.02 & 0.05 & 0.06 & -0.01 & 0.03 & 0.25 & -- & 0.13 & 0.03 & -0.01 \\
\hline$A V G \_I R$ & 16 & -0.04 & 0.03 & -0.01 & 0.04 & 0.10 & -0.24 & 0.33 & 0.28 & 0.02 & 0.22 & 0.51 & -0.20 & 0.11 & 0.30 & 0.30 & - & -0.05 & -0.01 \\
\hline UNAVal & 18 & 0.04 & 0.03 & 0.12 & 0.03 & 0.04 & 0.13 & -0.01 & 0.08 & -0.05 & -0.03 & 0.09 & 0.73 & -0.06 & 0.00 & 0.06 & -0.07 & 0.12 & - \\
\hline
\end{tabular}

The upper right-hand portion of the table presents Pearson product-moment correlations and the lower left-hand portion presents the Spearman rank-order correlations. Bold text indicates significance at the 0.01 level or better. $\mathrm{N}=7,765$. ACL_Distress $=1$ if the firm has at least one audit committee member that is an audit committee member or manager at a distressed interlock firm, 0 otherwise. SACL_Distress $=1$ if the firm's CEO or CFO is an audit committee member at a distressed interlock firm, 0 otherwise. ACSize $=$ the number of audit committee members at time $t$. FEP $=$ the proportion of audit committee members that are disclosed as being financial experts. LagDImpair $=1$ if the firm wrote off goodwill in the prior year, 0 otherwise. ExpWO $=1$ if market value of equity is less than book value of equity at time $t, 0$ otherwise. IndAdjMTB = firm ratio of market value of equity to book value of equity, adjusted by the mean value of the market to book ratio for the firm's 2 digit SIC code. ROA = earnings before interest, depreciation and taxes divided by average total assets. ChgROA = ROA at time $t$ less ROA at time $t-1$. Ret $=12$ month buy and hold return during year $t$. Size = market value of equity. Lev = total current and long term debt all divided by market value of equity. Delist $=$ 1 if the firm's shares are traded on the NASDAQ or NYSE, 0 otherwise. CEOTenure $=$ the number of years the CEO has held his current position. CFOTenure $=$ the number of years the CFO has held her position. AVG_IR = the firm-year mean incentive ratio for the CEO and CFO. LnSeg = the natural log of the number of disclosed segments. UNAVal $=-1 *$ [Cash + All Investments and Advances - Debt - Preferred Equity] $/$ [Assets - Liabilities]. 
TABLE 5

Logistic Regressions of Goodwill Impairment Decision on Interlock and Control Variables

\begin{tabular}{|c|c|c|c|c|}
\hline & $\begin{array}{l}\text { Control and Audit } \\
\text { Committee } \\
\text { Variables } \\
(1)\end{array}$ & $\begin{array}{l}\text { Test of H1: Links } \\
\text { to distressed firms } \\
\text { (2) }\end{array}$ & $\begin{array}{l}\text { Test of H2: } \\
\text { Imitation } \\
\text { hypothesis } \\
(3)\end{array}$ & $\begin{array}{l}\text { Test H3: Neutral } \\
\text { and Received } \\
\text { Links } \\
(4) \\
\end{array}$ \\
\hline \multirow[t]{2}{*}{ Intercept } & $-3.792 * * *$ & $-3.779 * * *$ & $-3.766^{* * *}$ & $-3.762 * * *$ \\
\hline & (216.564) & (209.988) & (207.476) & (211.431) \\
\hline ACL_Distress & & $0.274^{* *}$ & & \\
\hline \multirow[t]{2}{*}{ ACL_NoDistress } & & 0.100 & 0.098 & \\
\hline & & $(1.016)$ & (1.052) & \\
\hline \multirow[t]{2}{*}{ ACL_Impair } & & & $0.351^{* * *}$ & \\
\hline & & & (9.107) & \\
\hline \multirow[t]{2}{*}{ ACL_DistressNoImpair } & & & 0.072 & \\
\hline & & & $(0.294)$ & \\
\hline NACL_Distress & & & & $\begin{array}{c}0.109 \\
(1.275)\end{array}$ \\
\hline RACL_Distress & & & & $\begin{array}{l}0.418^{* * *} \\
(6.063)\end{array}$ \\
\hline \multirow[t]{2}{*}{ SACL_Distress } & & -0.011 & -0.020 & -0.040 \\
\hline & & $(0.003)$ & $(0.010)$ & $(0.041)$ \\
\hline \multirow[t]{2}{*}{ SACL_NoDistress } & & 0.077 & 0.076 & \\
\hline & & (0.557) & $(0.548)$ & \\
\hline \multirow[t]{2}{*}{ ACSize } & 0.030 & 0.024 & 0.024 & 0.026 \\
\hline & (1.417) & (0.944) & $(0.924)$ & (1.071) \\
\hline \multirow[t]{2}{*}{ FEP } & 0.080 & 0.061 & 0.051 & 0.072 \\
\hline & $(0.292)$ & (0.168) & (0.119) & $(0.238)$ \\
\hline \multirow[t]{2}{*}{ LagDImpair } & $1.357 * * *$ & $1.344 * * *$ & $1.345^{* * *}$ & $1.346^{* * *}$ \\
\hline & (122.969) & (120.380) & (119.984) & (120.071) \\
\hline \multirow[t]{2}{*}{ ExpWO } & $0.660^{* * *}$ & $0.662 * * *$ & $0.665^{* * *}$ & $0.660^{* * *}$ \\
\hline & (43.192) & (43.161) & (43.566) & (43.129) \\
\hline \multirow[t]{2}{*}{ IndAdjMTB } & $-0.039 * *$ & $-0.038 * *$ & $-0.037 * *$ & $-0.038 * *$ \\
\hline & $(4.985)$ & $(4.693)$ & $(4.600)$ & $(4.755)$ \\
\hline \multirow[t]{2}{*}{$R O A$} & $-1.129 * * *$ & $-1.253 * * *$ & $-1.250 * * *$ & $-1.273 * * *$ \\
\hline & (17.001) & (16.211) & (16.139) & (16.751) \\
\hline \multirow[t]{2}{*}{ ChgROA } & $-1.952 * * *$ & $-1.959 * * *$ & $-1.975^{* * *}$ & $-1.938 * * *$ \\
\hline & (15.845) & (15.885) & (16.197) & (15.573) \\
\hline \multirow[t]{2}{*}{ Ret } & $-1.068 * * *$ & $-1.060 * * *$ & $-1.064 * * *$ & $-1.066 * * *$ \\
\hline & (65.170) & (64.692) & (65.115) & (64.739) \\
\hline \multirow[t]{2}{*}{ Size } & -0.040 & $-0.055^{*}$ & $-0.056^{*}$ & -0.047 \\
\hline & (1.864) & 3.214 & (3.414) & (2.447) \\
\hline \multirow[t]{2}{*}{ Lev } & $0.121 * * *$ & $0.118 * * *$ & $0.117^{* * *}$ & $0.120 * * *$ \\
\hline & (21.677) & (20.528) & (20.178) & (20.775) \\
\hline \multirow[t]{2}{*}{ Delist } & -0.052 & -0.060 & -0.056 & -0.054 \\
\hline & (0.117) & (0.157) & (0.138) & (0.128) \\
\hline \multirow[t]{2}{*}{ CEOTenure } & -0.004 & -0.003 & -0.003 & -0.004 \\
\hline & $(0.595)$ & $(0.358)$ & $(0.288)$ & $(0.434)$ \\
\hline \multirow{2}{*}{ CFOTenure } & -0.014 & -0.014 & -0.014 & -0.014 \\
\hline & (2.331) & (2.215) & (2.179) & (2.256) \\
\hline
\end{tabular}


TABLE 5

Logistic Regressions of Goodwill Impairment Decision on Interlock and Control Variables

\begin{tabular}{rcccc}
\multicolumn{5}{c}{ (Continued) } \\
\hline LnSeg & $0.266^{* * *}$ & $0.267 * * *$ & $0.267 * * *$ & $0.270^{* * *}$ \\
& $(23.177)$ & $(23.224)$ & $(23.247)$ & $(23.849)$ \\
UNAVal & -0.001 & -0.001 & -0.001 & -0.001 \\
& $(0.351)$ & $(0.377)$ & $(0.358)$ & $(0.365)$ \\
Industry, Auditor and & & & & \\
Year, Fixed Effects & & & YES & YES \\
Included & YES & YES & 7,765 & 7,765 \\
$N$ & 7,765 & 0.194 & 0.195 & .195 \\
\hline Pseudo R-Square & 0.193 & & &
\end{tabular}

Chi-square statistics are presented in parentheses. ${ }^{* * *}, * *$, and * indicate significance at the $.01, .05$ and .10 levels, respectively. Cluster-robust standard errors are presented, and are clustered on firm. The independent variable, DImpair, is equal to 1 if the focal firm wrote off goodwill in year $t, 0$ otherwise. ACL_Distress $=1$ if the firm has at least one audit committee member that is an audit committee member or manager at a distressed interlock firm, 0 otherwise. ACL_NoDistress $=1$ if the firm has audit committee members who participate only on audit committees or are managers of non-distressed interlock firms, 0 otherwise. ACL_Impair $=1$ if the firm has at least one audit committee member that is an audit committee member or manager at a firm that wrote off goodwill in the prior year, 0 otherwise. ACL_DistressNoImpair $=1$ if the firm has at least one audit committee member that is an audit committee member or manager at a distressed interlock firm that did not write off goodwill in the prior year, 0 otherwise. NACL_Distress $=1$ if the firm has at least one audit committee member that is an audit committee member at a distressed interlock firm, 0 otherwise. RACL_Distress $=1$ if the firm has at least one audit committee member that is a manager at a distressed interlock firm, 0 otherwise. SACL_Distress $=1$ if the firm's CEO or CFO is an audit committee member at a distressed interlock firm, 0 otherwise. SACL_NoDistress $=1$ if the CEO or CFO participates only on audit committees of non-distressed interlock firms. ACSize $=$ the number of audit committee members at time t. FEP $=$ the proportion of audit committee members that are disclosed as being financial experts. LagDImpair $=1$ if the firm wrote off goodwill in the prior year, 0 otherwise. ExpWO $=1$ if market value of equity is less than book value of equity at time $t, 0$ otherwise. IndAdjMTB = firm ratio of market value of equity to book value of equity, adjusted by the mean value of the market to book ratio for the firm's 2 digit SIC code. ROA = earnings before interest, depreciation and taxes divided by average total assets. ChgROA $=$ ROA at time $t$ less ROA at time $t-1$. Ret $=12$ month buy and hold return during year $t$. Size = market value of equity. Lev = total current and long term debt all divided by market value of equity. Delist $=1$ if the firm's shares are traded on the NASDAQ or NYSE, 0 otherwise. CEOTenure $=$ the number of years the CEO has held his current position. CFOTenure $=$ the number of years the CFO has held her position LnSeg = the natural log of the number of disclosed segments. UNAVal = the in-sample rank of [ $-1 *[$ Cash + All Investments and Advances - Debt - Preferred Equity] / [Assets - Liabilities]]. 
TABLE 6

Marginal Effects of Goodwill Impairment Decision on Interlock and Control Variables

\begin{tabular}{|c|c|c|c|c|}
\hline & $\begin{array}{c}\text { Control and Audit } \\
\text { Committee } \\
\text { Variables } \\
(1) \\
\end{array}$ & $\begin{array}{l}\text { Test of H1: Links } \\
\text { to distressed firms } \\
\text { (2) }\end{array}$ & $\begin{array}{l}\text { Test of H2: } \\
\text { Imitation } \\
\text { Hypothesis } \\
\text { (3) } \\
\end{array}$ & $\begin{array}{l}\text { Test of H3: } \\
\text { Neutral and } \\
\text { received } \\
\text { independent } \\
\text { variables } \\
(4) \\
\end{array}$ \\
\hline ACL_Distress & & 0.024 & & \\
\hline ACL_NoDistress & & 0.008 & 0.008 & \\
\hline ACL_Impair & & & 0.031 & \\
\hline ACL_DistressNoImpair & & & 0.006 & \\
\hline NACL_Distress & & & & 0.009 \\
\hline RACL_Distress & & & & 0.039 \\
\hline SACL_Distress & & -0.001 & 0.002 & -0.003 \\
\hline SACL_NoDDistress & & 0.006 & 0.006 & \\
\hline ACSize & 0.004 & 0.003 & 0.003 & 0.003 \\
\hline FEP & 0.002 & 0.001 & 0.001 & 0.002 \\
\hline LagDImpair & 0.170 & 0.168 & 0.168 & 0.214 \\
\hline ExpWO & 0.065 & 0.066 & 0.066 & 0.065 \\
\hline IndAdjMTB & -0.010 & -0.009 & -0.009 & -0.009 \\
\hline$R O A$ & -0.011 & -0.014 & -0.013 & -0.014 \\
\hline ChgROA & -0.013 & -0.013 & -0.041 & -0.012 \\
\hline Ret & -0.043 & -0.039 & -0.009 & -0.039 \\
\hline Size & -0.007 & -0.008 & 0.013 & -0.008 \\
\hline Lev & 0.014 & 0.013 & -0.005 & 0.013 \\
\hline Delist & -0.001 & -0.005 & -0.002 & -0.001 \\
\hline CEOTenure & -0.002 & -0.002 & -0.002 & -0.002 \\
\hline CFOTenure & -0.005 & -0.005 & -0.005 & -0.005 \\
\hline LnSeg & 0.017 & 0.017 & 0.017 & 0.012 \\
\hline UNAVal & -0.002 & -0.002 & -0.002 & -0.002 \\
\hline$N$ & 7,765 & 7,765 & 7,765 & 7,765 \\
\hline Probability of write-off & 0.095 & 0.088 & 0.088 & 0.094 \\
\hline
\end{tabular}
bold.

Marginal effects related to coefficients that are statistically significant at the $\mathrm{p}<0.05$ level or better are in

The probability of write-off is calculated as $\pi(x)=e^{\beta^{\prime} X} /\left(1+e^{\beta^{\prime} X}\right)$ where $\beta^{\prime} X$ is calculated using the mean values of $X$. Changes in probability (or marginal effects) are calculated as the change in probability of write-off given a change in the independent variable, holding the other independent variables constant at their mean values. For dichotomous variables, the change in probability is calculated by changing the value from 0 to 1 , and for continuous variable by changing the value from the sample mean to one standard deviation above the sample mean.

ACL_Distress $=1$ if the firm has at least one audit committee member that is an audit committee member or manager at a distressed interlock firm, 0 otherwise. ACL_NoDistress $=1$ if the firm has audit committee members who participate only on audit committees or are managers of non-distressed interlock firms, 0 otherwise. ACL_Impair $=1$ if the firm has at least one audit committee member that is an audit committee member or manager at a firm that wrote off goodwill in the prior year, 0 otherwise. ACL_DistressNoImpair $=1$ if the firm has at least one audit committee 


\section{TABLE 6}

\section{Marginal Effects of Goodwill Impairment Decision on Interlock and Control Variables}

\section{(Continued)}

member that is an audit committee member or manager at a distressed interlock firm that did not write off goodwill in the prior year, 0 otherwise. NACL_Distress $=1$ if the firm has at least one audit committee member that is an audit committee member at a distressed interlock firm, 0 otherwise. RACL_Distress $=1$ if the firm has at least one audit committee member that is a manager at a distressed interlock firm, 0 otherwise. SACL_Distress $=1$ if the firm's CEO or CFO is an audit committee member at a distressed interlock firm, 0 otherwise. SACL_NoDistress $=1$ if the CEO or CFO participates only on audit committees of non-distressed interlock firms. ACSize $=$ the number of audit committee members at time $t$. FEP $=$ the proportion of audit committee members that are disclosed as being financial experts. LagDImpair $=1$ if the firm wrote off goodwill in the prior year, 0 otherwise. ExpWO $=1$ if market value of equity is less than book value of equity at time $t, 0$ otherwise. IndAdjMTB = firm ratio of market value of equity to book value of equity, adjusted by the mean value of the market to book ratio for the firm's 2 digit SIC code. ROA = earnings before interest, depreciation and taxes divided by average total assets. ChgROA = ROA at time $t$ less ROA at time $t-1$. Ret $=12$ month buy and hold return during year $t$. Size = market value of equity. Lev $=$ total current and long term debt all divided by market value of equity. Delist $=1$ if the firm's shares are traded on the NASDAQ or NYSE, 0 otherwise. CEOTenure $=$ the number of years the CEO has held his current position. CFOTenure $=$ the number of years the CFO has held her position. LnSeg = the natural log of the number of disclosed segments. UNAVal = the insample rank of [-1*[Cash + All Investments and Advances - Debt - Preferred Equity] / [Assets - Liabilities]]. 
TABLE 7

Logistic Regressions of Goodwill Impairment Decision on Interlock and Control Variables by Incentive Ratio Quartile

\begin{tabular}{|c|c|c|c|c|c|}
\hline & $\begin{array}{c}\text { All Sub-Sample } \\
\text { Firms }\end{array}$ & $1^{\text {st }}$ Quartile & $2^{\text {nd }}$ Quartile & $3^{\text {rd }}$ Quartile & $4^{\text {th }}$ Quartile \\
\hline \multirow[t]{2}{*}{ Intercept } & $-5.225 * * *$ & $-5.549 * * *$ & $-5.658 * * *$ & $-9.313^{* * *}$ & $-3.517 * * *$ \\
\hline & (193.147) & (79.755) & (50.809) & (145.875) & (10.625) \\
\hline \multirow[t]{2}{*}{ NACL_Distress } & 0.078 & 0.052 & 0.050 & 0.180 & -0.024 \\
\hline & $(0.397)$ & $(0.067)$ & $(0.035)$ & $(0.514)$ & $(0.005)$ \\
\hline \multirow[t]{2}{*}{ RACL_Distress } & $0.378^{*}$ & 0.395 & $0.750^{*}$ & 0.571 & 0.013 \\
\hline & (3.443) & $(0.938)$ & (3.018) & (1.937) & $(0.001)$ \\
\hline \multirow{2}{*}{ SACL_Distress } & -0.156 & 0.304 & -0.905 & -0.169 & 0.074 \\
\hline & $(0.364)$ & $(0.471)$ & $(2.434)$ & $(0.097)$ & $(0.013)$ \\
\hline \multirow[t]{2}{*}{ ACSize } & $0.064^{* *}$ & 0.034 & 0.047 & 0.042 & 0.097 \\
\hline & $(4.463)$ & $(0.560)$ & $(0.516)$ & $(0.460)$ & (1.765) \\
\hline \multirow[t]{2}{*}{ FEP } & -0.186 & $-0.654 *$ & -0.042 & -0.085 & 0.104 \\
\hline & (0.937) & (3.771) & $(0.010)$ & $(0.054)$ & $(0.045)$ \\
\hline \multirow[t]{2}{*}{ LagDImpair } & $1.313^{* * *}$ & $1.034^{* * *}$ & $1.353^{* * *}$ & $1.546^{* * *}$ & $1.485 * * *$ \\
\hline & (58.264) & (13.655) & (22.750) & (18.193) & (8.484) \\
\hline \multirow[t]{2}{*}{ ExpWO } & $0.737 * * *$ & $0.792 * * *$ & 0.449 & 0.406 & 0.110 \\
\hline & (21.140) & (12.274) & (1.806) & $(0.604)$ & $(0.028)$ \\
\hline \multirow[t]{2}{*}{ IndAdjMTB } & -0.023 & -0.029 & 0.021 & -0.068 & -0.033 \\
\hline & $(0.774)$ & $(0.587)$ & $(0.252)$ & (1.527) & $(0.184)$ \\
\hline \multirow[t]{2}{*}{$R O A$} & $-3.065 * * *$ & $-2.344 * *$ & -1.485 & $-5.345 * * *$ & $-4.762 * * *$ \\
\hline & (18.571) & $(4.464)$ & (0.909) & (12.710) & (6.723) \\
\hline \multirow[t]{2}{*}{ ChgROA } & $-2.001 * *$ & $-2.647 * *$ & -0.657 & -2.232 & $-6.719 * *$ \\
\hline & $(5.446)$ & $(4.674)$ & $(0.128)$ & $(0.911)$ & (5.556) \\
\hline \multirow[t]{2}{*}{ Ret } & $-0.996 * * *$ & $-0.973 * * *$ & $-0.666^{* *}$ & $-0.814^{* *}$ & $-2.197 * * *$ \\
\hline & (23.957) & (8.886) & (4.370) & (4.305) & (17.150) \\
\hline \multirow[t]{2}{*}{ Size } & $-0.082 *$ & 0.024 & -0.114 & 0.059 & -0.036 \\
\hline & 3.256 & $(0.077)$ & $(1.080)$ & $(0.415)$ & $(0.085)$ \\
\hline \multirow[t]{2}{*}{ Lev } & $0.190 * * *$ & $0.162 * * *$ & $0.851 * * *$ & $0.726^{*}$ & -0.083 \\
\hline & (15.946) & (7.856) & (12.915) & (3.314) & (0.509) \\
\hline \multirow[t]{2}{*}{ LnSeg } & $0.224 * * *$ & 0.180 & 0.189 & 0.193 & 0.131 \\
\hline & (9.039) & (1.971) & (1.458) & (1.609) & $(0.482)$ \\
\hline \multirow[t]{2}{*}{ UNAVal } & $-0.003^{*}$ & 0.001 & $-0.007 * *$ & 0.051 & -0.002 \\
\hline & (2.768) & $(0.004)$ & (4.658) & $(0.644)$ & $(0.013)$ \\
\hline \multicolumn{6}{|l|}{$\begin{array}{l}\text { Industry, Auditor, } \\
\text { and Year Fixed }\end{array}$} \\
\hline Effects Included & YES & YES & YES & YES & YES \\
\hline$N$ & 4,144 & 1,028 & 1,028 & 1,028 & 1,030 \\
\hline Pseudo R-Square & 19.67 & 23.05 & 17.11 & 17.12 & 21.35 \\
\hline
\end{tabular}

Chi-square statistics are presented in parentheses. ${ }^{* * *},{ }^{* *}$, and * indicate significance at the $.01, .05$ and .10

levels, respectively. Cluster-robust standard errors are presented, clustered by firm. The independent variable, DImpair, is equal to 1 if the focal firm wrote off goodwill in year $t, 0$ otherwise. NACL_Distress $=1$ if the firm has at least one audit committee member that is an audit committee member at a distressed interlock firm, 0 otherwise.

RACL_Distress = 1 if the firm has at least one audit committee member that is a manager at a distressed interlock firm, 0 otherwise. SACL_Distress $=1$ if the firm's CEO or CFO is an audit committee member at a distressed interlock firm, 0 otherwise. ACSize $=$ the number of audit committee members at time $t$. FEP $=$ the proportion of audit 


\section{TABLE 7}

Logistic Regressions of Goodwill Impairment Decision on Interlock and Control Variables by Incentive Ratio Quartile (Continued)

committee members that are disclosed as being financial experts. LagDImpair $=1$ if the firm wrote off goodwill in the prior year, 0 otherwise. LagDImpair $=1$ if the firm wrote off goodwill in the prior year, 0 otherwise. ExpWO = 1 if market value of equity is less than book value of equity at time $t, 0$ otherwise. IndAdjMTB = firm ratio of market value of equity to book value of equity, adjusted by the mean value of the market to book ratio for the firm's 2-digit SIC code. $\mathrm{ROA}=$ earnings before interest, depreciation and taxes divided by average total assets. ChgROA = ROA at time $t$ less ROA at time $t-1$. Ret $=12$ month buy and hold return during year $t$. Size $=$ market value of equity. Lev $=$ total current and long term debt all divided by market value of equity. LnSeg = the natural log of the number of disclosed segments. UNAVal $=$ the in-sample rank of $[-1 *[$ Cash + All Investments and Advances - Debt - Preferred Equity $] /$ [Assets - Liabilities]]. 
TABLE 8

Marginal Effects of Goodwill Impairment Decision on Interlock and Control Variables by Incentive Ratio Quartile

$1^{\text {st }}$ Quartile $\quad 2^{\text {nd }}$ Quartile $\quad 3^{\text {rd }}$ Quartile $\quad 4^{\text {th }}$ Quartile

\begin{tabular}{rrrrr} 
NACL_Distress & 0.007 & 0.003 & 0.010 & -0.001 \\
RACL_Distress & 0.060 & 0.057 & 0.039 & 0.000 \\
SACL_Distress & 0.045 & -0.036 & -0.009 & 0.003 \\
ACSize & 0.008 & 0.004 & 0.004 & 0.006 \\
FEP & -0.022 & -0.001 & -0.001 & 0.001 \\
LagDImpair & $\mathbf{0 . 1 7 6}$ & $\mathbf{0 . 1 2 3}$ & $\mathbf{0 . 1 5 1}$ & $\mathbf{0 . 0 9 3}$ \\
ExpWO & $\mathbf{0 . 1 2 6}$ & 0.030 & 0.026 & 0.004 \\
IndAdjMTB & -0.011 & 0.004 & -0.009 & -0.004 \\
ROA & $\mathbf{- 0 . 0 3 3}$ & -0.007 & $\mathbf{- 0 . 0 2 1}$ & $\mathbf{- 0 . 0 1 3}$ \\
ChgROA & $\mathbf{- 0 2 6}$ & -0.002 & -0.006 & $\mathbf{- 0 . 0 1 0}$ \\
Ret & $\mathbf{- 0 . 0 5 8}$ & $\mathbf{- 0 . 0 1 5}$ & $\mathbf{- 0 . 0 1 6}$ & $\mathbf{- 0 . 0 2 1}$ \\
Size & 0.002 & -0.007 & 0.005 & -0.000 \\
Lev & $\mathbf{0 . 0 4 6}$ & $\mathbf{0 . 0 3 0}$ & 0.034 & -0.002 \\
LnSeg & 0.019 & 0.008 & 0.009 & 0.004 \\
UNAVal & 0.001 & $\mathbf{- 0 . 0 1 0}$ & 0.026 & 0.000 \\
\hline$N$ & & & & \\
Probability of & 1,028 & 1,028 & 1,028 & 1,030 \\
write-off & & & & \\
& 0.191 & 0.063 & 0.061 & 0.035 \\
\hline
\end{tabular}

Marginal effects related to coefficients that are statistically significant at the $\mathrm{p}<0.05$ level or better are in bold.

The probability of write-off is calculated as $\pi(x)=e^{\beta^{\prime} X} /\left(1+e^{\beta^{\prime} X}\right)$ where $\beta^{\prime} X$ is calculated using the mean values of $X$. Changes in probability (or marginal effects) are calculated as the change in probability of write-off given a change in the independent variable, holding the other independent variables constant at their mean values. For dichotomous variables, the change in probability is calculated by changing the value from 0 to 1 , and for continuous variable by changing the value from the sample mean to one standard deviation above the sample mean.

NACL_Distress $=1$ if the firm has at least one audit committee member that is an audit committee member at a distressed interlock firm, 0 otherwise. RACL_Distress $=1$ if the firm has at least one audit committee member that is a manager at a distressed interlock firm, 0 otherwise. SACL_Distress $=1$ if the firm's CEO or CFO is an audit committee member at a distressed interlock firm, 0 otherwise. ACSize $=$ the number of audit committee members at time $t$. FEP $=$ the proportion of audit committee members that are disclosed as being financial experts. ExpWO $=1$ if market value of equity is less than book value of equity at time $t, 0$ otherwise. IndAdjMTB $=$ firm ratio of market value of equity to book value of equity, adjusted by the mean value of the market to book ratio for the firm's 2 digit SIC code. $\mathrm{ROA}=$ earnings before interest, depreciation and taxes divided by average total assets. ChgROA $=\mathrm{ROA}$ at time $t$ less ROA at time $t-1$. Ret $=12$ month buy and hold return during year $t$. Size $=$ market value of equity. Leverage $=$ total current and long term debt all divided by market value of equity. AVG_IR is equal to the firm-year mean incentive ratio for the CEO and CFO. LnSeg = the natural log of the number of disclosed segments. UNAVal = the insample rank of [-1*[Cash + All Investments and Advances - Debt - Preferred Equity] / [Assets - Liabilities]]. 
TABLE 9

Two-Stage Heckman Model

Panel A: First stage - propensity to be linked to a distressed firm

\begin{tabular}{rcr} 
& Estimate & Chi-Square \\
\hline Intercept & $-5.549^{* * *}$ & 115.874 \\
LnPool & 0.052 & 0.036 \\
ACsize & $0.395^{*}$ & 2.741 \\
$F E P$ & $0.304^{* *}$ & 5.318 \\
$G W$ & 0.034 & 0.041 \\
ExpWO & $-0.655^{*}$ & 3.356 \\
IndAdjMTB & 1.034 & 0.604 \\
ROA & 0.792 & 1.408 \\
ChgROA & -0.029 & 0.197 \\
Ret & $-2.345^{* * *}$ & 35.735 \\
Size & $-2.647^{* * *}$ & 92.024 \\
Lev & $-0.973^{* *}$ & 5.450 \\
Delist & $0.024^{*}$ & 2.888 \\
CEOTenure & $0.162^{* * *}$ & 11.242 \\
CFOTenure & $0.181^{* *}$ & 5.192 \\
& & \\
\hline Industry Fixed & & \\
Effects included & & \\
$N$ & 6,383 & \\
Pseudo R-Square & 0.051 & \\
\hline
\end{tabular}

Panel B: Estimation of Equation (2) including Inverse Mills ratio

\begin{tabular}{|c|c|}
\hline & $\begin{array}{l}\text { Heckman Second Stage } \\
\text { Model }\end{array}$ \\
\hline Intercept & $\begin{array}{l}-0.448 \\
(0.471)\end{array}$ \\
\hline ACL_NoDistress & $\begin{array}{c}0.141 \\
(1.671)\end{array}$ \\
\hline ACL_Impair & $\begin{array}{l}0.371^{* * *} \\
(8.528)\end{array}$ \\
\hline ACL_DistressNoImpair & $\begin{array}{c}0.116 \\
(0.657)\end{array}$ \\
\hline SACL_Distress & $\begin{array}{c}0.003 \\
(0.000)\end{array}$ \\
\hline SACL_NoDistress & $\begin{array}{c}0.074 \\
(0.512)\end{array}$ \\
\hline ACSize & $\begin{array}{c}0.010 \\
(0.717)\end{array}$ \\
\hline FEP & $\begin{array}{l}-0.310 * \\
(3.468)\end{array}$ \\
\hline
\end{tabular}


TABLE 9

Two-Stage Heckman Model (Continued)

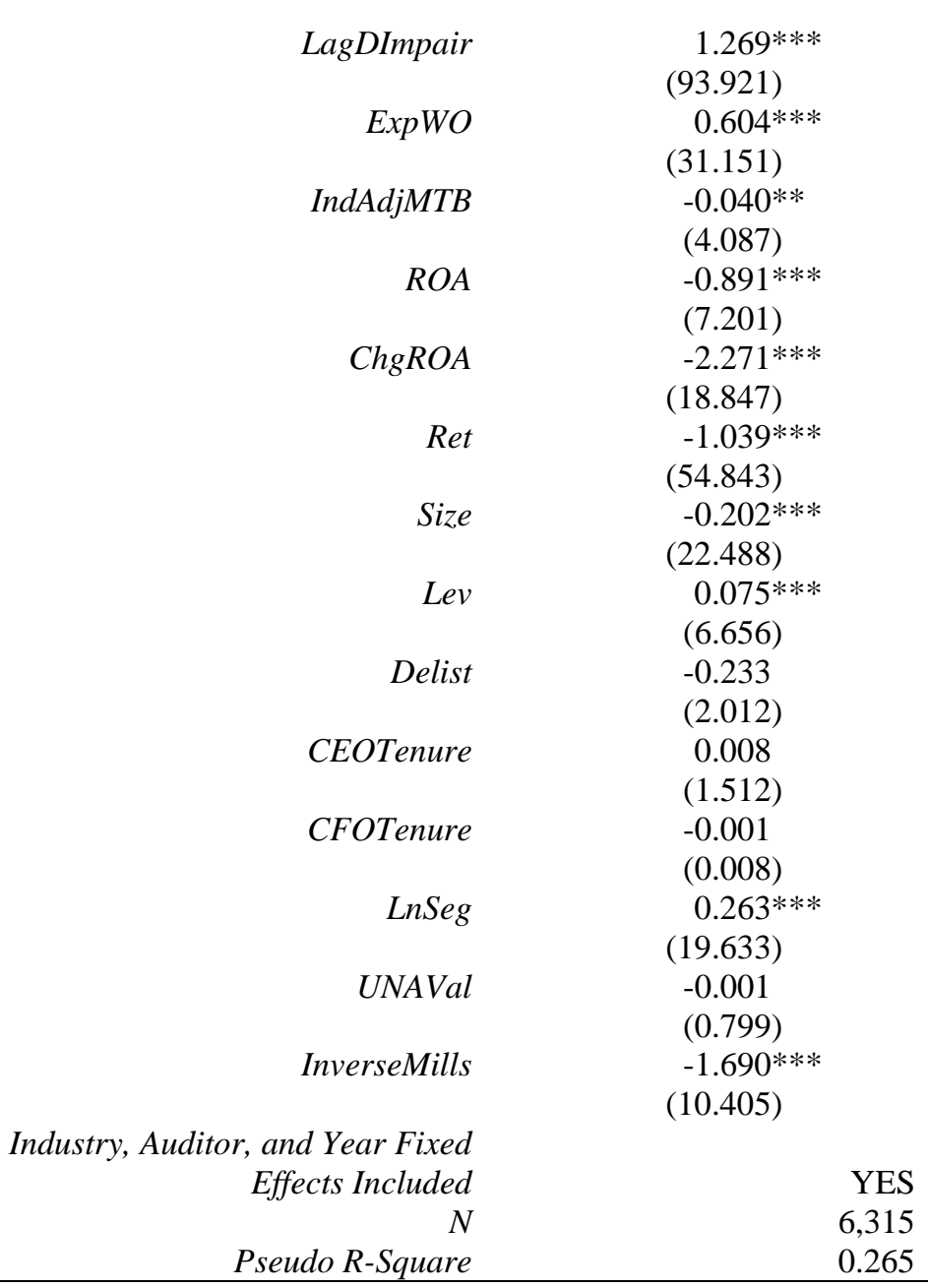

Chi-square statistics are presented in parentheses. ${ }^{* * *}, * *$, and $*$ indicate significance at the $.01, .05$ and .10 levels, respectively. Cluster-robust standard errors are presented, and are clustered on firm.

The independent variable in Panel A, ACL_Distress = 1 if the firm has at least one audit committee member that is an audit committee member or manager at a distressed interlock firm, 0 otherwise. The independent variable in Panel $\mathrm{B}$, DImpair, is equal to 1 if the focal firm wrote off goodwill in year $t, 0$ otherwise. LnPool = the natural log of the number of audit committee members in the firm-year's geographic region. ACSize = the number of audit committee members at time $t$. FEP = the proportion of audit committee members that are disclosed as being financial experts. GW $=$ the dollar amount of beginning of year goodwill. ExpWO = 1 if market value of equity is less than book value, 0 otherwise. IndAdjMTB = firm ratio of market value of equity to book value of equity, adjusted by the mean value of the market to book ratio for the firm's 2 digit SIC code. ROA = earnings before interest, depreciation and taxes divided by average total assets. ChgROA $=$ ROA at time $t$ less ROA at time $t-1$. Ret $=12$ month buy and hold return during year $t$. Size = market value of equity. Lev = total current and long term debt all divided by market value of equity. Delist $=1$ if the firm's shares are traded on the NASDAQ or NYSE, 0 otherwise. CEOTenure $=$ the number of years the CEO has held his current position. CFOTenure = the number of years the CFO has held her position. 


\section{TABLE 9}

Two-Stage Heckman Model (Continued)

ACL_NoDistress $=1$ if the firm has audit committee members who participate only on audit committees or are managers of non-distressed interlock firms, 0 otherwise. ACL_Impair = 1 if the firm has at least one audit committee member that is an audit committee member or manager at a firm that wrote off goodwill in the prior year, 0 otherwise. ACL_DistressNoImpair $=1$ if the firm has at least one audit committee member that is an audit committee member or manager at a distressed interlock firm that did not write off goodwill in the prior year, 0 otherwise. SACL_Distress $=1$ if the firm's CEO or CFO is an audit committee member at a distressed interlock firm, 0 otherwise. SACL_NoDistress $=1$ if the CEO or CFO participates only on audit committees of non-distressed interlock firms. LnSeg = the natural log of the number of disclosed segments. UNAVal $=$ the in-sample rank of [ $-1 *$ [Cash + All Investments and Advances Debt - Preferred Equity] / [Assets - Liabilities]]. 
TABLE 10

Propensity Score Matched Sample

\section{Panel A: Covariate balance between matched pairs}

\begin{tabular}{rrrr} 
& $\begin{array}{c}\text { Mean } \\
\text { Treatment }\end{array}$ & $\begin{array}{c}\text { Mean } \\
\text { Control }\end{array}$ & $\begin{array}{c}\text { t-Test } \\
\text { Difference } \\
\text { p-value }\end{array}$ \\
\hline LnPool & 8.151 & 8.164 & 0.212 \\
ACSize & 4.442 & 4.460 & 0.792 \\
FEP & 0.470 & 0.469 & 0.895 \\
$G W$ & 1060.700 & 1017.000 & 0.776 \\
ExpWO & 0.107 & 0.107 & 1.000 \\
IndAdjMTB & -0.062 & -0.058 & 0.975 \\
ROA & 0.119 & 0.120 & 0.890 \\
ChgROA & -0.003 & -0.004 & 0.477 \\
Ret & 0.010 & 0.012 & 0.909 \\
Size & 7.056 & 7.060 & 0.958 \\
Lev & 0.498 & 0.502 & 0.926 \\
Delist & 0.949 & 0.954 & 0.543 \\
CEOTenure & 6.442 & 6.428 & 0.953 \\
CFOTenure & 4.490 & 4.513 & 0.886 \\
& & & \\
\hline Industry Fixed & & & \\
Effects included & & & \\
$N$ & 1,425 & 1,425 & \\
\hline
\end{tabular}

Panel B: Estimation of Equation (2) using propensity matched sample

\begin{tabular}{rc} 
& $\begin{array}{c}\text { Propensity Score } \\
\text { matched Sample }\end{array}$ \\
\hline Intercept & $-6.479^{* * *}$ \\
& $(224.981)$ \\
ACL_NoDistress & $0.382^{* *}$ \\
& $(4.261)$ \\
ACL_Impair & $0.483^{* * *}$ \\
& $(7.846)$ \\
ACL_DistressNoImpair & 0.192 \\
& $(1.197)$ \\
SACL_Distress & -0.207 \\
& $(0.235)$ \\
SACL_NoDistress & 0.235 \\
& $(2.685)$ \\
ACSize & $0.083^{* *}$ \\
& $(5.344)$ \\
FEP & -0.109 \\
& $(0.266)$
\end{tabular}


TABLE 10

Propensity score matched sample (Continued)

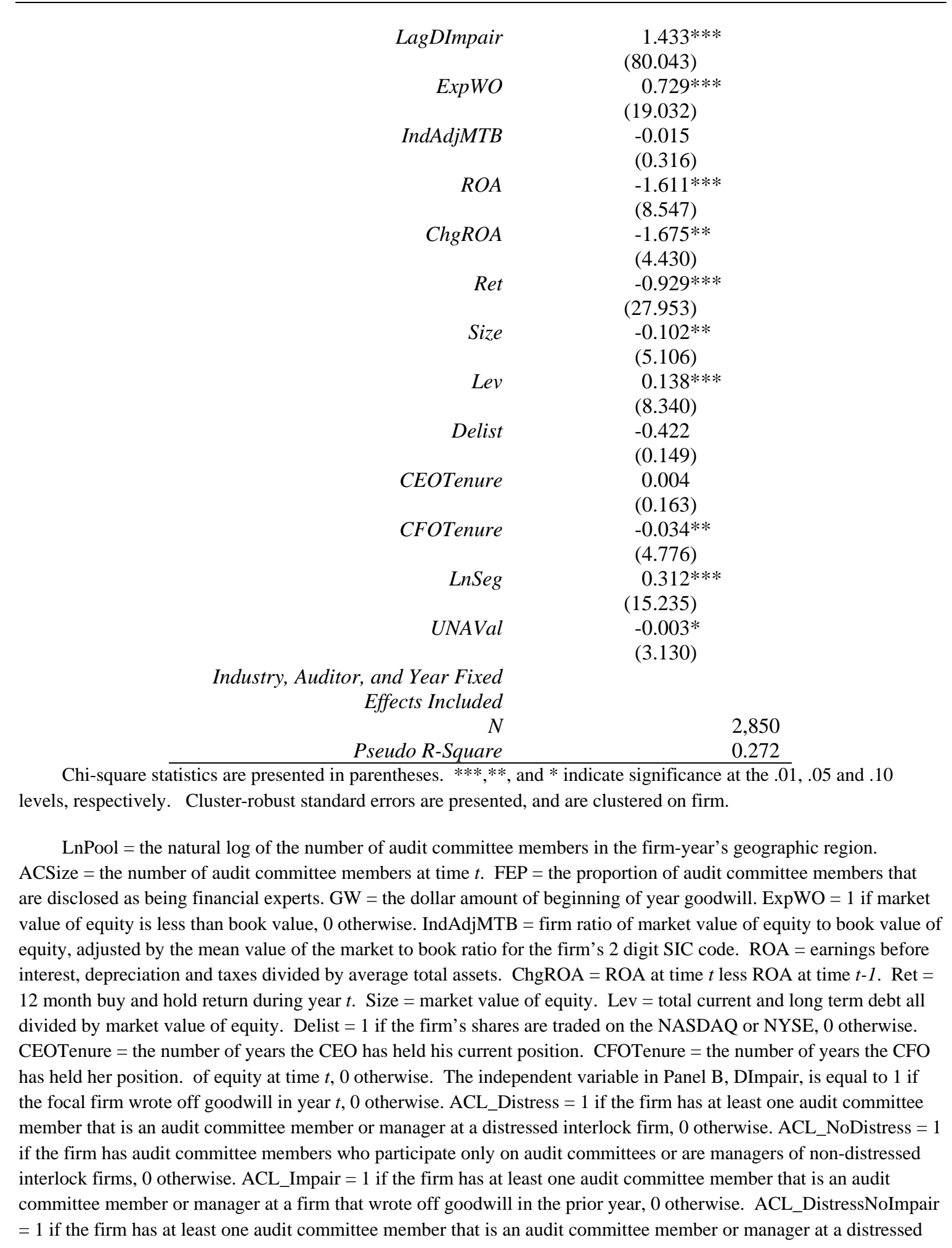




\section{TABLE 10}

Propensity score matched sample (Continued)

interlock firm that did not write off goodwill in the prior year, 0 otherwise. SACL_Distress $=1$ if the firm's CEO or CFO is an audit committee member at a distressed interlock firm, 0 otherwise. SACL_NoDistress $=1$ if the CEO or CFO participates only on audit committees of non-distressed interlock firms. LnSeg $=$ the natural log of the number of disclosed segments. UNAVal $=$ the in-sample rank of $[-1 *[$ Cash + All Investments and Advances - Debt - Preferred Equity] / [Assets - Liabilities]]. 
TABLE 11

Differences in Means of Independent Variables Within High and Low Propensity Write-off Firms

\section{Differences in distributions by propensity to write off and actual write-off behavior}

\begin{tabular}{|c|c|c|c|c|c|c|c|c|c|c|c|c|c|c|c|}
\hline & & & $n$ & $\mathrm{ACL}_{-}$ & istress & $\begin{array}{c}\text { p- } \\
\text { value }\end{array}$ & ACL_N & Distress & $\begin{array}{c}\text { p- } \\
\text { value }\end{array}$ & ACL_I & Impair & $\begin{array}{c}\text { p- } \\
\text { value }\end{array}$ & ACL_D & ToImpair & $\begin{array}{c}\mathrm{p}- \\
\text { value }\end{array}$ \\
\hline $\begin{array}{l}\text { High Pr / } \\
\text { Write off }\end{array}$ & $\begin{array}{l}\text { High Pr / No } \\
\text { Write off }\end{array}$ & 335 & 245 & 0.322 & 0.249 & 0.056 & 0.484 & 0.486 & 0.960 & 0.215 & 0.171 & 0.194 & 0.146 & 0.118 & 0.332 \\
\hline $\begin{array}{l}\text { Low Pr / } \\
\text { Write off }\end{array}$ & $\begin{array}{l}\text { Low } \operatorname{Pr} / \text { No } \\
\text { Write off }\end{array}$ & 751 & 6,314 & 0.268 & 0.204 & $<0.001$ & 0.525 & 0.569 & 0.019 & 0.194 & 0.135 & $<0.001$ & 0.104 & 0.086 & 0.102 \\
\hline
\end{tabular}

P-values calculated based upon the Wilcoxon two-sample difference test. Firms are considered High Pr (high probability of write-off) if the calculated probability of write-off is greater than .40 , otherwise firms are considered Low Pr (low probability of write-off). ACL_Distress = 1 if the firm has at least one audit committee member that is an audit committee member or manager at a distressed interlock firm, 0 otherwise. ACL_NoDistress = 1 if the firm has audit committee members who participate only on audit committees or are managers of non-distressed interlock firms, 0 otherwise. ACL_Impair $=1$ if the firm has at least one audit committee member that is an audit committee member or manager at a firm that wrote off goodwill in the prior year, 0 otherwise. ACL_DistressNoImpair $=1$ if the firm has at least one audit committee member that is an audit committee member or manager at a distressed interlock firm that did not write off goodwill in the prior year, 0 otherwise. 


\section{References}

Advisory Committee on Improvements to Financial Reporting. (CIFiR). 2008. Final

Report of the Advisory Committee on Improvements to Financial Reporting to the United States Securities and Exchange Commission.

Ahmed A. and S. Duellman. 2007. Accounting conservatism and board of director characteristics: An empirical analysis. Journal of Accounting and Economics 43: $411-$ 437.

Adams, R., B. Hermalin, and M. Weisbach. 2010. The Role of Boards of Directors in Corporate Governance: A Conceptual Framework and Survey. Journal of Economic Literature 48: 58 - 107.

Agoglia, C., T. Doupnik, and G. Tsakumis. 2011. Principles-Based versus Rules-Based Accounting Standards: The Influence of Standard Precision and Audit Committee Strength on Financial Reporting Decisions. The Accounting Review 86: 747-767.

Armstrong, C., W. Guay, and J. Weber. 2011. The Role of Information and Financial Reporting in Corporate Governance and Debt Contracting. Journal of Accounting and Economics 50: 179-234.

Armstrong, C., A. Jagolinzer, and D. Larcker. 2010. Chief Executive Officer Equity Incentives and Accounting Irregularities. Journal of Accounting Research 48: 225 - 270.

Banerjee, A. 1992. A Simple Model of Herd Behavior. The Quarterly Journal of Economics 107: 797 - 817.

Barth, M. and W. Landsman. 2010. How did Financial Reporting Contribute to the Financial Crisis? The European Accounting Review 19: 399-423.

Beasley, M. 1996. An Empirical Analysis of the Relation Between the Board of Director Composition and Financial Statement Fraud. The Accounting Review 71: 443 - 465.

Beasley, M., J. Carcello, D. Hermanson, and T. Neal. 2009. The Audit Committee Oversight Process. Contemporary Accounting Research 26: 65 - 122.

Beatty, A. and J. Weber. 2006. Accounting Discretion in Fair Value Estimates: An Examination of SFAS 142 Goodwill Impairments. Journal of Accounting Research 44: $257-288$. 
Beckman, C. and P.R. Haunschild. 2002. Network Learning: The Effects of Partners' Heterogeneity of Experience on Corporate Acquisitions. Administrative Science Quarterly 47: 92 - 124.

Bergstresser, D. and T. Philippon. 2006. CEO incentives and earnings management. Journal of Financial Economics 80: 511 - 529.

Bikhchandani, S., D. Hirshleifer, and I. Welch. 1992. A theory of fads, fashion, custom, and cultural-change as informational cascades. Journal of Political Economy 100: 9921026.

Bizjak, J., M. Lemmon, and R. Whitby. 2009. Option Backdating and Board Interlocks. The Review of Financial Studies 22: 4821 - 4847.

Bouwman, C. 2011. Corporate Governance Propagation through Overlapping Directors. The Review of Financial Studies 24: 2358 - 2394.

Bowen, R., S. Rajgopal, and M. Venkatachalam. 2008. Accounting Discretion, Corporate Governance, and Firm Performance. Contemporary Accounting Research 25: $351-405$.

Brown, J.L. 2011. The Spread of Aggressive Corporate Tax Reporting: A Detailed Examination of the Corporate-Owned Life Insurance Shelter. The Accounting Review 86(1): 23-57.

Carcello, J. and T. Neal. 2003. Audit Committee Characteristics and Auditor Dismissals following "New" Going-Concern Reports. The Accounting Review 78: 95 - 117.

Carcello, J. and T. Neal. 2000. Audit Committee Composition and Auditor Reporting. The Accounting Review 75: 453 - 467.

Carcello, J., C. Hollingsworth, A. Klein, and T. Neal. 2009. The Role of Audit Committee Financial Experts in the Post-SOX Era: Have Smaller Public Companies Benefitted Disproportionately? Working Paper, University of Tennessee.

Chen, C. and B. Goh. 2010. Contagion Effect of Restatements through Common Directorships. Working Paper, Singapore Management University.

Chiu, P.C., S.H. Teoh, and F. Tian. 2010. Board Interlocks and Earnings Management Contagion. Working Paper, University of California - Irvine. Available at SSRN: http://ssrn.com/abstract=1723714. 
Cohen, J., G. Krishnamoorthy, and A. Wright. 2008. Form versus Substance: The Implications for Auditing Practice and Research of Alternative Perspectives on Corporate Governance. Auditing: A Journal of Practice and Theory 27: 181 - 198.

Davis, G.F. 1991. Agents without Principles? The Spread of the Poison Pill through the Intercorporate Network. Administrative Science Quarterly 36: 583 - 613.

Defond, M., R. Hann, and X. Hu. 2005. Does the Market Value Financial Expertise on Audit Committees Boards of Directors? Journal of Accounting Research 43: 154 - 193.

Dey, A. 2008. Corporate Governance and Agency Conflicts. Journal of Accounting Research 46: 1143 - 1181.

Dey, A. and X. Liu. 2011. Social Connections, Stock-Based Compensation and Director Oversight. Working Paper, University of Minnesota.

DiMaggio, P. and W. Powell. 1983. The iron cage revisited: Institutional isomorphism and collective rationality in organizational fields. American Sociological Review 48: 147160.

Fama, E. and M. Jensen. 1983. Separation of Ownership and Control. Journal of Law and Economics 26: $301-325$.

Farber, D. 2005. Restoring Trust after Fraud: Does Corporate Governance Matter? The Accounting Review 80 (2): 539 - 561.

Fich, E. and A. Shivdasani. 2006. Are Busy Boards Effective Monitors? Journal of Finance 61: 689 - 724.

Financial Accounting Standards Board (FASB). Statement of Financial Accounting Standards 142: Goodwill and Other Intangible Assets. Norwalk, CT: FASB 2001.

Financial Accounting Standards Board (FASB). Statement of Financial Accounting Standards 157: Fair Value Measurements. Norwalk, CT: FASB 2007.

Fligstein, N. 1985. The Spread of the Multidivisional Form Among Large Firms, 1919 1979. American Sociological Review 50: 377 - 391.

Francis, J., J.D. Hanna, and L. Vincent. 1996. Causes and Effects of Discretionary Asset Write-Offs. Journal of Accounting Research 34: 117 - 134. 
Galaskiewicz, J. and S. Wasserman. 1989. Mimetic Processes within an Interorganizational Field: An Empirical Test. Administrative Science Quarterly 34: 454 79.

Gleason, C., N. Jenkins, and W.B. Johnson. 2008. The Contagion Effects of Accounting Restatements. The Accounting Review 83: 83 - 110.

Goh, B.W. 2009. Audit Committees, Boards of Directors and Remediation of Material Weaknesses in Internal Control. Contemporary Accounting Research 26: 549 - 579.

Guler, L. 2007. Goodwill impairment charges under SFAS 142: Role of executives' incentives and corporate governance. Texas A\&M University Dissertation.

Haunschild, P. R. 1993. Interorganizational imitation: The impact of interlocks on corporate acquisition activity. Administrative Science Quarterly 38: 564 - 592.

Haunschild, P.R. 1994. How Much is that Company Worth?: Interorganizational Relationships, Uncertainty, and Acquisition Premiums. Administrative Science Quarterly 39: $391-411$.

Haunschild, P.R. and C. Beckman. 1998. When Do Interlocks Matter?: Alternate Sources of Information and Interlock Influence. Administrative Science Quarterly 43: $815-844$.

Hawley, A. 1968. Human Ecology. David L. Sills International Encyclopedia of the Social Sciences. New York: MacMillan. Pp. 328 - 337.

Hayn, C. and P. Hughes. 2006. Leading Indicators of Goodwill Impairment. Journal of Accounting, Auditing and Finance 21: 223 - 265.

Heckman, J. 1978. Dummy Endogenous Variable in a Simultaneous Equation System. Econometrica 46: 931-959.

Hermalin, B. and M. Weisbach. 1998. Endogenously Chosen Boards of Directors and Their Monitoring of the CEO. American Economic Review 88: 96 - 118.

Klein, A. 2002. Audit committee, board of director characteristics, and earnings management. Journal of Accounting and Economics 33: 375-400.

Larcker, D., S. Richardson, and I. Tuna. 2007. Corporate Governance, Accounting Outcomes, and Organizational Performance. The Accounting Review 82: 963 - 1008. 
Li, K. and R. Sloan. 2009. Has Goodwill Accounting Gone Bad? Working Paper, University of California Berkeley.

Li, Z., P. Shroff, R. Venkataraman, and I. Zhang. 2010. Causes and Consequences of Goodwill Impairment Losses. Working Paper, University of Minnesota. Available at SSRN: http://ssrn.com/abstract=590908.

McDaniel, L., R. Martin, and L. Maines. 2002. Evaluating Financial Reporting Quality: The Effects of Financial Expertise vs. Financial Literacy. The Accounting Review 77: $139-167$.

Monks, R. and N. Minnow. 2008. Corporate Governance. John Wiley and Sons Ltd. West Sussex, England.

Public Company Accounting Oversight Board (PCAOB). 2010. Proposed Auditing Standard Related to Communications with Audit Committees and Related Amendments to Certain PCAOB Auditing Standards. PCOAB Release No. 2010-001. March 29.

. 2010. PCAOB Issues Reporting on Inspection Observations of Auditing During the Economic Crisis. September 29.

Ramanna, K. 2008. The implications of unverifiable fair-value accounting: Evidence from the political economy of goodwill accounting. Journal of Accounting and Economics 45: 253 - 281.

Ramanna, K. and R. Watts. 2011. Evidence on the use of unverifiable estimates in required goodwill impairment. Working paper, Harvard Business School. Available at SSRN: http://ssrn.com/abstract=1134943.

Rosenbaum, P. and D. Rubin. 1983. The Central Role of the Propensity Score in Observational Studies for Causal Effects. Biometrika 70: 41-55.

Shi, L, R. Dharwadkar, and D. Harris. 2011. Financial Accounting Practices and Interlocked Corporate Governance. Working paper, Binghamton University SUNY. Available at SSRN: http://ssrn.com/abstract=1976856.

Srinivasan, S. 2005. Consequences of Financial Reporting Failure for Outside Directors: Evidence from Accounting Restatements and Audit Committee Members. Journal of Accounting Research 43: 291 - 334.

U.S. Congress. 2002. The Sarbanes-Oxley Act of 2002 (SOX). Public Law No. 107 204. Washington, D.C.: Government Printing Office. 


\section{Vita}

Marcy Lynn Shepardson was born in Cincinnati, Ohio to W. Philip and Nancy Shepardson. She has one older brother, Brian Shepardson. Marcy attended high school at Turpin High School in Cincinnati, and graduated in 1994. She then attended Michigan State University where she received her Bachelor of Arts in Accounting from the Eli Broad College of Business in 1998. Marcy received her CPA license from the state of California where she worked for Arthur Andersen and Deloitte \& Touche in their San Diego offices. Marcy’s primary research interests are the effects of auditing and audit committees on financial reporting and auditing and financial reporting standards.

Permanent Address: shepardm@indiana.edu

This manuscript was typed by the author. 